Article

\title{
Phthalocyanine-Grafted Titania Nanoparticles for Photodegradation of Ibuprofen
}

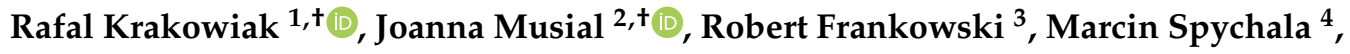 \\ Jadwiga Mielcarek ${ }^{5}$, Bernadeta Dobosz ${ }^{6}$, Ryszard Krzyminiewski ${ }^{6}$, Marek Sikorski ${ }^{7}{ }^{\mathbb{D}}$, \\ Wioletta Bendzinska-Berus ${ }^{1}$ (D) Ewa Tykarska ${ }^{1}$ (D), Ryszard Blazejewski ${ }^{4}$, \\ Agnieszka Zgoła-Grześkowiak ${ }^{3}$ D , Beata J. Stanisz ${ }^{2}$, Dariusz T. Mlynarczyk 1,*D \\ and Tomasz Goslinski ${ }^{1}$ (D) \\ 1 Chair and Department of Chemical Technology of Drugs, Poznan University of Medical Sciences, \\ Grunwaldzka 6, 60-780 Poznań, Poland; rlkrakowiak@gmail.com (R.K.); wiolettab88@tlen.pl (W.B.-B.); \\ etykarsk@ump.edu.pl (E.T.); tomasz.goslinski@ump.edu.pl (T.G.) \\ 2 Chair and Department of Pharmaceutical Chemistry, Poznan University of Medical Sciences, \\ Grunwaldzka 6, 60-780 Poznań, Poland; joannaa.musial@gmail.com (J.M.); bstanisz@ump.edu.pl (B.J.S.) \\ 3 Institute of Chemistry and Technical Electrochemistry, Poznan University of Technology, Berdychowo 4, \\ 60-965 Poznań, Poland; robert.frankowski@put.poznan.pl (R.F.); \\ agnieszka.zgola-grzeskowiak@put.poznan.pl (A.Z.-G.) \\ 4 Department of Hydraulic and Sanitary Engineering, Poznan University of Life Sciences, Piątkowska 94A, \\ 60-649 Poznań, Poland; marcin.spychala@up.poznan.pl (M.S.); rblaz@up.poznan.pl (R.B.) \\ 5 Chair and Department of Inorganic and Analytical Chemistry, Poznan University of Medical Sciences, \\ Grunwaldzka 6, 60-780 Poznan, Poland; jmielcar@ump.edu.pl \\ 6 Medical Physics and Radiospectroscopy Division, Faculty of Physics, Adam Mickiewicz University, \\ Uniwersytetu Poznańskiego 2, 61-614 Poznań, Poland; benia@amu.edu.pl (B.D.); rku@amu.edu.pl (R.K.) \\ 7 Faculty of Chemistry, Adam Mickiewicz University, Uniwersytetu Poznańskiego 8, 61-614 Poznań, Poland; \\ sikorski@amu.edu.pl \\ * Correspondence: mlynarczykd@ump.edu.pl; Tel.: +48-61-854-66-33; Fax: +48-61-854-66-39 \\ + authors declare equal contribution.
}

Received: 19 October 2020; Accepted: 11 November 2020; Published: 15 November 2020

\begin{abstract}
The natural environment is constantly under threat from man-made pollution. More and more pharmaceuticals are recognized as emerging pollutants due to their growing concentration in the environment. One such chemical is ibuprofen which has been detected in processed sewage. The ineffectiveness of water methods treatment currently used raises the need for new remediation techniques, one of such is photodegradation of pollutants. In the present study, zinc(II) and copper(II) phthalocyanines were grafted onto pure anatase $\mathrm{TiO}_{2}$ nanoparticles (5 and $15 \mathrm{~nm}$ ) to form photocatalysts for photodecomposition of ibuprofen in water. The nanoparticles were subjected to physicochemical characterization, including: thermogravimetric analysis, $\mathrm{X}$-ray powder diffraction, X-ray photoelectron spectroscopy, Brunauer-Emmett-Teller surface area analysis and particle size measurements. In addition, they were assessed by means of electron spin resonance spectroscopy to evaluate the free radical generation. The materials were also tested for their photocatalytic activity under either UV $(365 \mathrm{~nm})$ or visible light $(665 \mathrm{~nm})$ irradiation. After $6 \mathrm{~h}$ of irradiation, almost complete removal of ibuprofen under UV light was observed, as assessed by liquid chromatography coupled to mass spectrometry. The reaction kinetics calculations revealed that the copper(II) phthalocyanine-containing nanoparticles were acting at a faster rate than those with zinc(II) derivative. The solutions after the photoremediation experiments were subjected to Microtox ${ }^{\circledR}$ acute toxicity analysis.
\end{abstract}

Keywords: ibuprofen; microtox; photoremediation; phthalocyanine; titanium dioxide 


\section{Introduction}

The natural environment all around the globe is constantly deteriorating due to human activity. The wholesale loss of animal species is associated with environmental damage as a result of decreasing natural habitats, an increase in air and seas temperatures, as well as change in ecosystems caused by alarmingly increasing concentrations of chemicals $[1,2]$. With the constant development of our civilization and growing industrialization, we are facing new problems within our environment. They concern an improper utilization of chemical contaminants, including industrial wastes, pharmaceuticals and cosmetics [3]. Many substances end up in the natural environment due to thoughtless disposal of wastes or abuse of drugs. Now labeled as emerging contaminants, they often pose a threat to the environment due to their inherent toxicity to plants and animals. When deposited in the ground, these wastes can travel and end up in water reservoirs spreading toxicity and endangering human health. Furthermore, this is an issue of grave importance given that technology employed in contemporary water treatment facilities cannot effectively remove all of the substances belonging to this broad group [4].

As previously stated, drugs and drug-derived molecules constitute a group of compounds that are considered an emerging threat to the environment [5]. Traces of many pharmaceutically and biologically active compounds are often reported in the environment as the result of their manufacturing, use and improper disposal (Figure 1) [6,7]. Some pharmaceuticals undergo degradation in wastewaters and therefore do not pose any human health or environmental threat but some compounds can remain unchanged for a significant time [8]. Pharmaceuticals and their metabolites escape into wastewater mostly through the domestic, hospital or veterinary use, the pharmaceutical industry or animal farming [8-13]. Since many sewage treatment plants do not possess tools to effectively remove these compounds, they remain in the effluents and, eventually, their traces can be found in drinking water [14]. One of such compounds is a non-steroid anti-inflammatory drug-ibuprofen, dispensed over the counter in the pharmacy, which is not removed entirely from the waste-water in water-treatment plants [4]. Considerable adverse effects on human health resulting from exposure to very low levels of pharmaceuticals in drinking water are very unlikely, according to the World Health Organization (WHO) report from 2011 [15]. However, the report highlighted a few issues, which remain unsolved until this day, one of which being knowledge gaps associated with long-term, low-level exposure to pharmaceuticals. Little is also known about the combined effects of their mixtures, especially for sensitive subpopulations. It is noteworthy that global spending on medicines has been growing in recent years and is predicted to exceed $\$ 1.5$ trillion by 2023 [16]. This is one of the main reasons why new technologies of remediation are being pursued.

Although the WHO report provided recommendations on managing such concerns [15], technological solutions for wastewater, which would guarantee complete removal of all residues, are not yet in place [13]. Conventional wastewater treatments are often not effective enough, for example due to the low biodegradability of many pharmaceutical compounds. Therefore, attention more recently has been turned to alternative approaches, which include bioremediation, advanced oxidation processes (AOPs), ultrasonic treatment or adsorption techniques [5,17]. Among other AOPs, which employ the intermediacy of highly reactive species in order to decay the pollutant [7], photoremediation seems to be a promising method, especially when titanium(IV) oxide (titanium dioxide, $\mathrm{TiO}_{2}$ ) is used as the photocatalyst [18]. Various studies have already assessed this way of decomposing ibuprofen (IBU) in water solutions [4,19-21]. There is also evidence that $\mathrm{TiO}_{2}$ samples impregnated with photosensitizers, for example, porphyrins and phthalocyanine derivatives, enhance the degradation efficiency of organic pollutants [22]. 


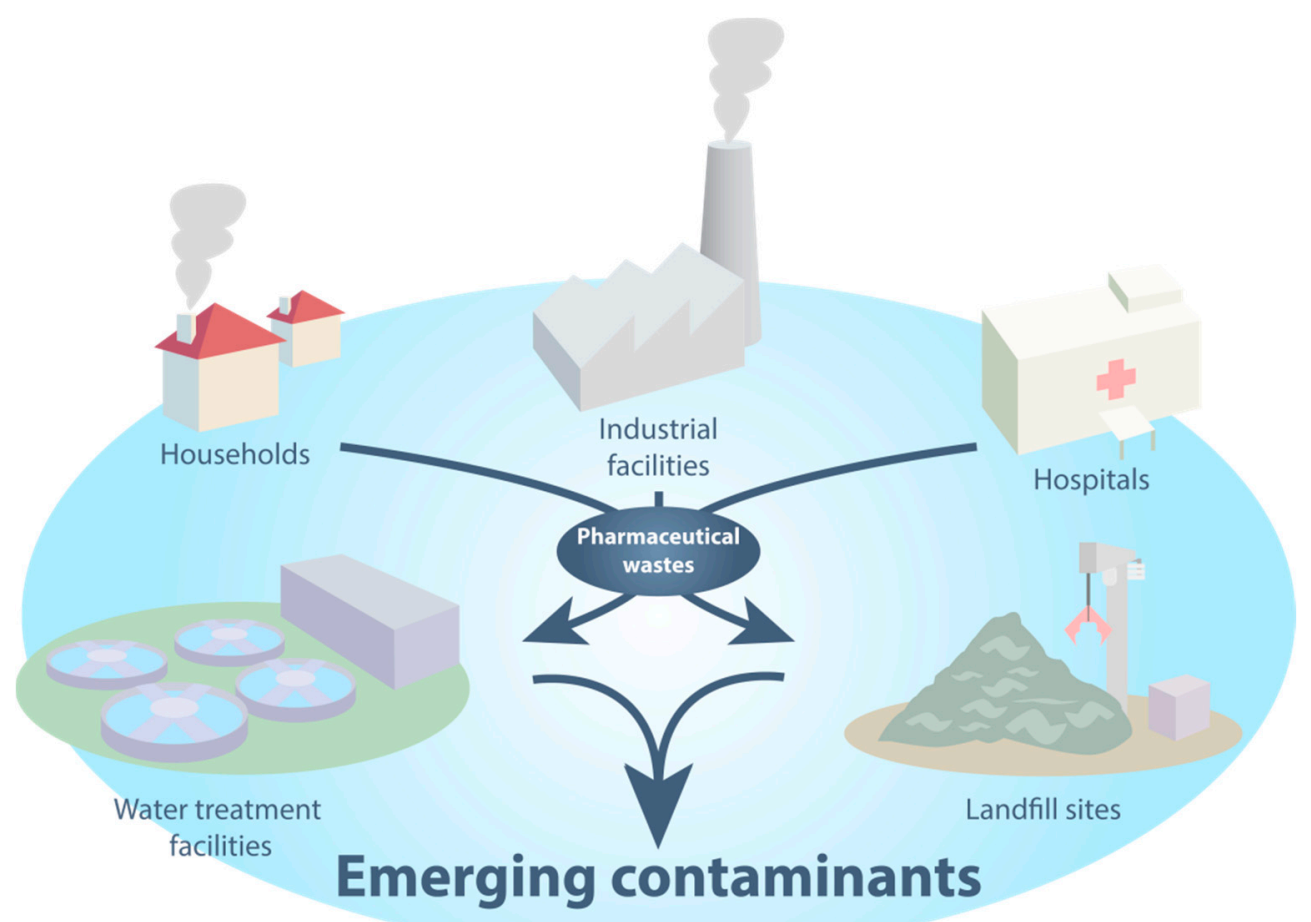

Figure 1. Schematic representation of sources of emerging contaminants.

Photoremediation is a relatively cheap and efficient method for removal of chemical contaminants. The process uses photocatalytic degradation of chemicals by exposing the photosensitizer to UV-Vis light. The photosensitizer absorbs energy from the light, which can then be transferred to the molecules present in the reaction environment. The released energy can interact with oxygen producing reactive oxygen species such as superoxides, singlet oxygen or hydroxyl radicals [23]. Metal oxides, such as zinc(II) oxide and titanium(IV) oxide, belong to chemical compounds that have so far been most commonly applied as photosensitizers in various photoremediation studies [24]. $\mathrm{TiO}_{2}$ has been used for the degradation of pharmaceuticals belonging to various groups, including antibiotics, analgesics, anticonvulsants, $\beta$-blockers, lipid regulators, non-steroid anti-inflammatory drugs, psychiatric drugs [25]. The results of broad studies are promising, with near $100 \%$ removal efficiency of pollutants in many cases being achieved. However, it is worth noting that in most experiments, the UV light, which is not an optimal source of light in water solutions, was applied [26]. This is due to the $\mathrm{TiO}_{2}$ band gap that only allows absorption of light below $387 \mathrm{~nm}$. Ideally, for water remediation purposes one would require a material that is active under exposure to visible light, which is mainly dictated by its cost-effectiveness. Functionalization of $\mathrm{TiO}_{2}$ surface can significantly improve its physicochemical properties. One way of such functionalization is grafting the surface with macrocyclic porphyrinoid compounds like porphyrazines and phthalocyanines $(\mathrm{Pc})$. These compounds reveal a broad excitation band that includes a visible light region. Additionally, the periphery of porphyrinoids can be modified, which even further enhances the desired characteristics [27]. By depositing porphyrinoid compounds on $\mathrm{TiO}_{2}$ surface it was possible to obtain hybrid materials that can be excited by the visible light [28].

In this work, we present the results of our studies where nanometric size $\mathrm{TiO}_{2}$ particles were functionalized with copper(II) and zinc(II) phthalocyanines (CuPc and $\mathrm{ZnPc}$, respectively). The obtained materials were characterized in terms of their physicochemical properties, using particle size distribution, X-ray powder diffraction (XRPD), X-ray photoelectron spectroscopy (XPS), thermogravimetric analysis (TGA), Brunauer-Emmett-Teller (BET) surface area analysis and electron spin resonance (ESR) spectroscopy, as well as prospective utility for water remediation. Therefore, the $\mathrm{TiO}_{2}-\mathrm{Pc}$ composites were assessed for their photocatalytic activity towards photodegradation of ibuprofen, which is a common pharmaceutical water pollutant. The decomposition was monitored 
by liquid chromatography coupled to mass spectrometry (LC-MS/MS) and the acute toxicity of the resulting solutions was evaluated using Microtox ${ }^{\circledR}$.

\section{Results and Discussion}

\subsection{Preparation and Characterization of the Nanoparticles}

The prepared materials were based on commercially available anatase phase titanium(IV) oxide nanoparticles. The choice of this crystalline phase was based firstly on the highest photoactivity of the anatase and secondly on the best stability of anatase nanoparticles in such a small diameter [28-30]. The nanoparticles (NPs) were prepared using the $\mathrm{Pc}: \mathrm{TiO}_{2}$ ratio of $1: 100$, based on the optimal activity observed for similar materials [31]. The researched phthalocyanines were chosen according to their high photoactivity-ZnPc $[32,33]$ and earlier reported effectiveness in photoremediation-CuPc $[22,31,34]$. Prepared nanomaterials, based on $5 \mathrm{~nm}$ and $15 \mathrm{~nm} \mathrm{TiO}{ }_{2}$ grafted with zinc(II) or copper(II) phthalocyanine, are summarized in Table 1.

Table 1. Hybrid $\mathrm{TiO}_{2}-\mathrm{Pc}$ materials applied in the study.

\begin{tabular}{ccc}
\hline $\mathrm{TiO}_{2}$ Nanoparticle Size & Pc, Pc $: \mathbf{T i O}_{2}$ Ratio $(\mathrm{m} / \mathrm{m})$ & Symbol of the Material \\
\hline $5 \mathrm{~nm}$ & $\mathrm{CuPc}, 1: 100$ & $1 \% \mathrm{CuPc} @ \mathrm{TiO}_{2}(5 \mathrm{~nm})$ \\
\hline $5 \mathrm{~nm}$ & $\mathrm{ZnPc}, 1: 100$ & $1 \% \mathrm{ZnPc} @ \mathrm{TiO}_{2}(5 \mathrm{~nm})$ \\
\hline $15 \mathrm{~nm}$ & $\mathrm{CuPc}, 1: 100$ & $1 \% \mathrm{CuPc} @ \mathrm{TiO}_{2}(15 \mathrm{~nm})$ \\
\hline $15 \mathrm{~nm}$ & $\mathrm{ZnPc}, 1: 100$ & $1 \% \mathrm{ZnPc} @ \mathrm{TiO}_{2}(15 \mathrm{~nm})$ \\
\hline
\end{tabular}

All the prepared materials, along with neat $\mathrm{TiO}_{2} \mathrm{NPs}$, were first subjected to physicochemical characterization to confirm later their potential usefulness for photoremediation. The applied techniques included: TGA, XRPD, particle size and BET surface area measurements, as well as ESR.

\subsection{Thermoanalysis}

The determination of the phase composition of Pc-grafted $\mathrm{TiO}_{2}$ photocatalysts was based on thermogravimetry results by analyzing the loss of mass (\%), as well as the rate of mass loss during heating. In the case of unmodified commercial $\mathrm{TiO}_{2}$ (anatase), two distinct stages were observed. The first (up to $120{ }^{\circ} \mathrm{C}$ ) was associated with water desorption (2.1\%) [35]. In the second stage (temperature range of $120^{\circ} \mathrm{C}-500{ }^{\circ} \mathrm{C}$ ), which was accompanied by approx. $3.71 \%$ weight loss, there was a release of chemically bound water molecules observed. Water molecules in this step were formed as a result of the condensation of the surface hydroxyl groups. The obtained results are consistent with the literature data. Many authors emphasize that the temperature range of $120-500{ }^{\circ} \mathrm{C}$ is suitable for separating physically adsorbed and chemically bound water molecules [35]. It is assumed that as a result of further heating to $900{ }^{\circ} \mathrm{C}$, the $\mathrm{TiO}_{2}$ surface becomes free of $\mathrm{OH}$ surface groups.

In the thermograms of the two analyzed phthalocyanines-ZnPc and $\mathrm{CuPc}-\mathrm{a}$ similar effect can be observed-heating to $120{ }^{\circ} \mathrm{C}$ resulted in approx. $2.6 \%$ loss of adsorbed water. However, further heating to $670{ }^{\circ} \mathrm{C}$, resulted in rapid decompositions of the Pcs, which were accompanied by about $62 \%$ weight loss. After exceeding this temperature, reductions in the decomposition rates (to $900^{\circ} \mathrm{C}$ ) were observed.

Titanium(IV) oxide composites with $\mathrm{ZnPc}$ and CuPc deposited by surface impregnation were also subjected to TGA. Samples containing commercial $\mathrm{TiO}_{2}$ with a particle size of $5 \mathrm{~nm}$ and $15 \mathrm{~nm}$ were analyzed. Quantitative evaluation of the obtained thermograms showed that heating in the temperature range of $20-120{ }^{\circ} \mathrm{C}$ resulted in approx. $3 \%$ weight loss caused by the desorption of adsorbed water. However, as a result of further heating, approx. 5\% weight loss was observed, which could be associated with the condensation of surface hydroxyl groups $\left(120-500{ }^{\circ} \mathrm{C}\right)$ accompanied by water release and the decomposition of phthalocyanine $\left(300-500^{\circ} \mathrm{C}\right)$. It was found that the smaller $5 \mathrm{~nm}$ particles expressed a higher loss of mass during the analysis than their $15 \mathrm{~nm}$ counterparts, 
regardless of their functionalization. This fact could be attributed to the higher surface area of $5 \mathrm{~nm}$ particles and would further translate to the number of hydroxyl groups present at the surface that could be thermally condensed with water release. However, no regularities were found when comparing bare titania nanoparticles to $\mathrm{ZnPc}$ or $\mathrm{CuPc}$ grafted materials, regardless of their sizes.

Exemplary thermograms of $\mathrm{TiO}_{2}$ nanocomposites with Pcs are presented in Figure 2.
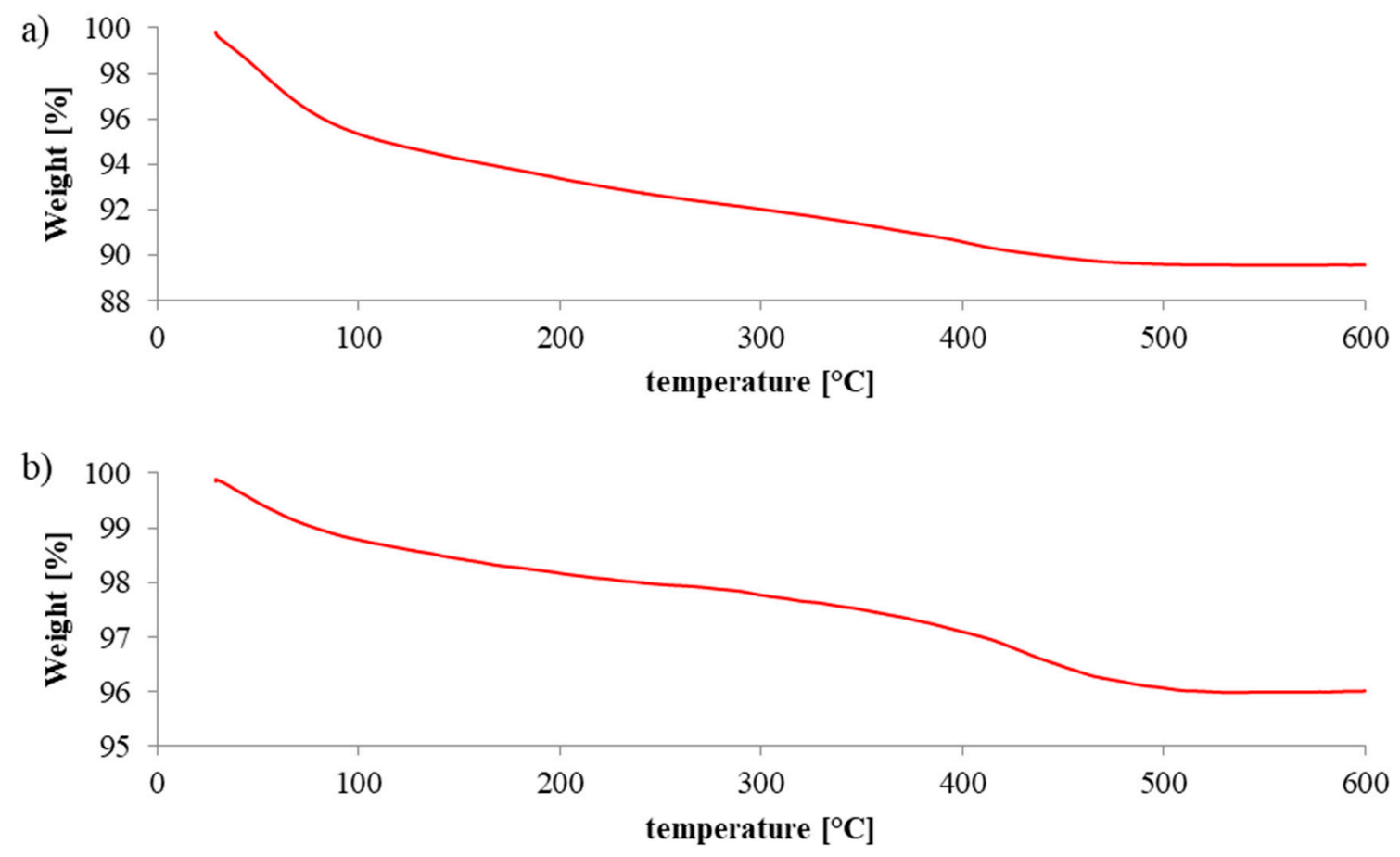

Figure 2. Thermograms of (a) $1 \% \mathrm{CuPc}_{\mathrm{TiO}}$ (5 nm) (b) $1 \% \mathrm{CuPc} @ \mathrm{TiO}_{2}(15 \mathrm{~nm})$.

\subsection{X-ray Powder Diffraction Analysis}

All the prepared materials were subjected to XRPD experiments. As presented in Figure 3, there is no difference between the diffraction patterns of neat $\mathrm{TiO}_{2}$ nanoparticles and $\mathrm{NPs}$ grafted with either $\mathrm{ZnPc}$ or $\mathrm{CuPc}$. It is consistent with the literature reports since it is assumed that in such composites, macrocyclic compounds occur as amorphous substances dispersed on $\mathrm{TiO}_{2}$ surface $[32,35,36]$. The reflections observed in the diffractograms of $1 \% \mathrm{Cu} / 1 \% \mathrm{ZnPc} @ \mathrm{TiO}_{2}$ correspond to the anatase phase, suggesting that the Pc deposition method used does not change the polymorph of titanium dioxide. In diffraction patterns of $5 \mathrm{~nm} \mathrm{TiO}{ }_{2}$ materials a decrease in peak intensity and broadening of peaks in comparison to $15 \mathrm{~nm} \mathrm{TiO}_{2}$ materials is observed. This finding can be related to the smaller size of crystallites [37]. Calculation of the crystallite sizes using Scherrer equation showed no differences between the initial bare titania nanoparticles and the final materials prepared from the respective size particles. 


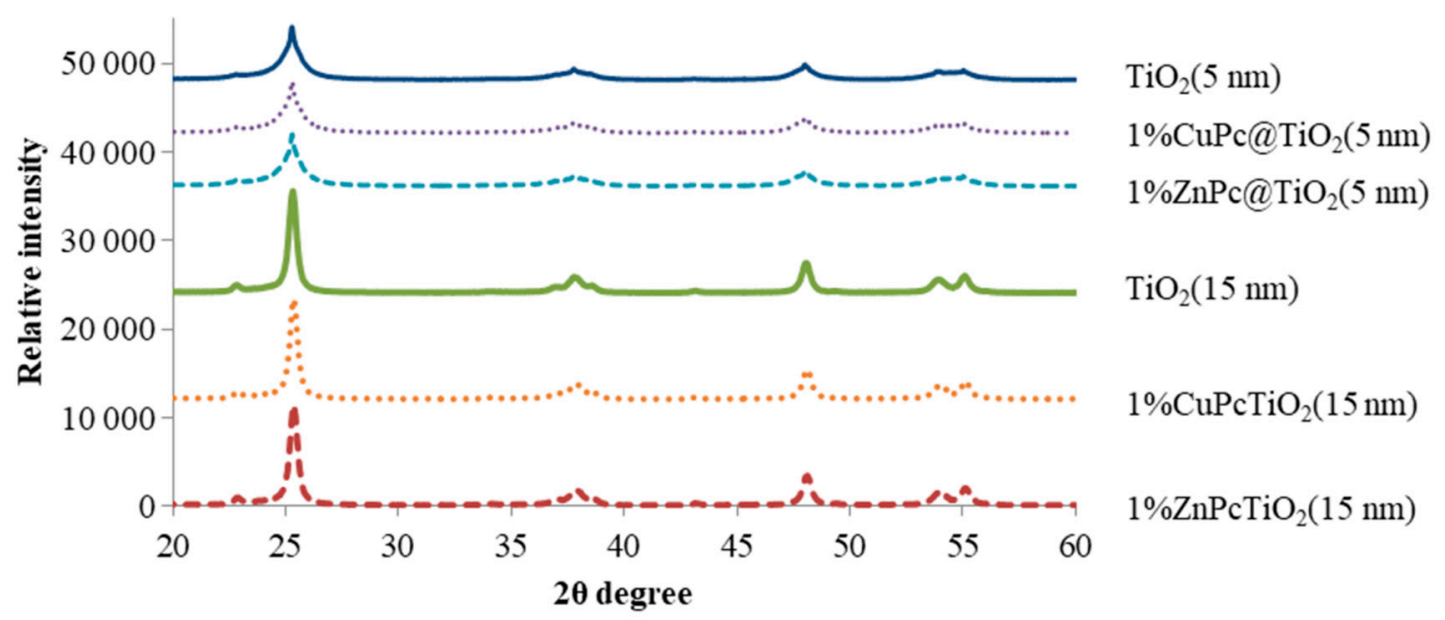

Figure 3. X-ray powder diffraction (XRPD) patterns of the prepared materials.

\subsection{XPS}

All the prepared materials were subjected to X-ray photoelectron spectroscopy experiments to detect the binding energy on the bare $\mathrm{TiO}_{2}$ and $\mathrm{TiO}_{2}$-phthalocyanine catalysts. The obtained spectra are collected in Figure 4. In the spectra of all the materials, signals from Ti, $\mathrm{O}$ and $\mathrm{C}$ can be observed, as labeled in Figure 4a. The drop in intensity of the peaks is visible in the $15 \mathrm{~nm} \mathrm{Pc}_{\mathrm{TiO}} \mathrm{Titerials}_{2}$ (see Figure 4d-f) in comparison to $5 \mathrm{~nm} \mathrm{Pc@TiO} 2$ (see Figure 4a-c), which is related to their lower surface area. Most notably, due to lack of covalent bonding, there were no noticeable shifts found when comparing the spectra of bare $\mathrm{TiO}_{2}$ and $\mathrm{Pc} @ \mathrm{TiO}_{2}$. The probable mode of binding of the phthalocyanines to titanium dioxide nanoparticles is via the oxygen atoms of $\mathrm{TiO}_{2}$, either through hydrogen bonding or coordination of the Pc by the oxygen lone electron pairs [38]. Therefore, in the spectra, the presence of $\mathrm{O} 1 \mathrm{~s}$ signals at $530.75 \mathrm{eV}$ and $530.91 \mathrm{eV}$ for a bare $\mathrm{TiO}_{2}(5 \mathrm{~nm})$ and both $\mathrm{Pc}$-grafted $\mathrm{TiO}_{2}(5 \mathrm{~nm})$, respectively, were noted. The presence of the low-intensity $\mathrm{C} 1$ s carbon signal for bare $\mathrm{TiO}_{2}$ samples was attributed to the adsorption of airborne $\mathrm{CO}_{2}$ on their surface [39]. The significant increase of $\mathrm{C}$ 1s intensity is observed in the spectra of Pc-grafted $\mathrm{TiO}_{2}$ materials. The lack of nitrogen, as well as $\mathrm{Zn}$ and $\mathrm{Cu}$ signals in the spectra, is caused by the very low content of these elements in the studied $1 \% \mathrm{Pc} @ \mathrm{TiO}_{2}$ materials [40]. 

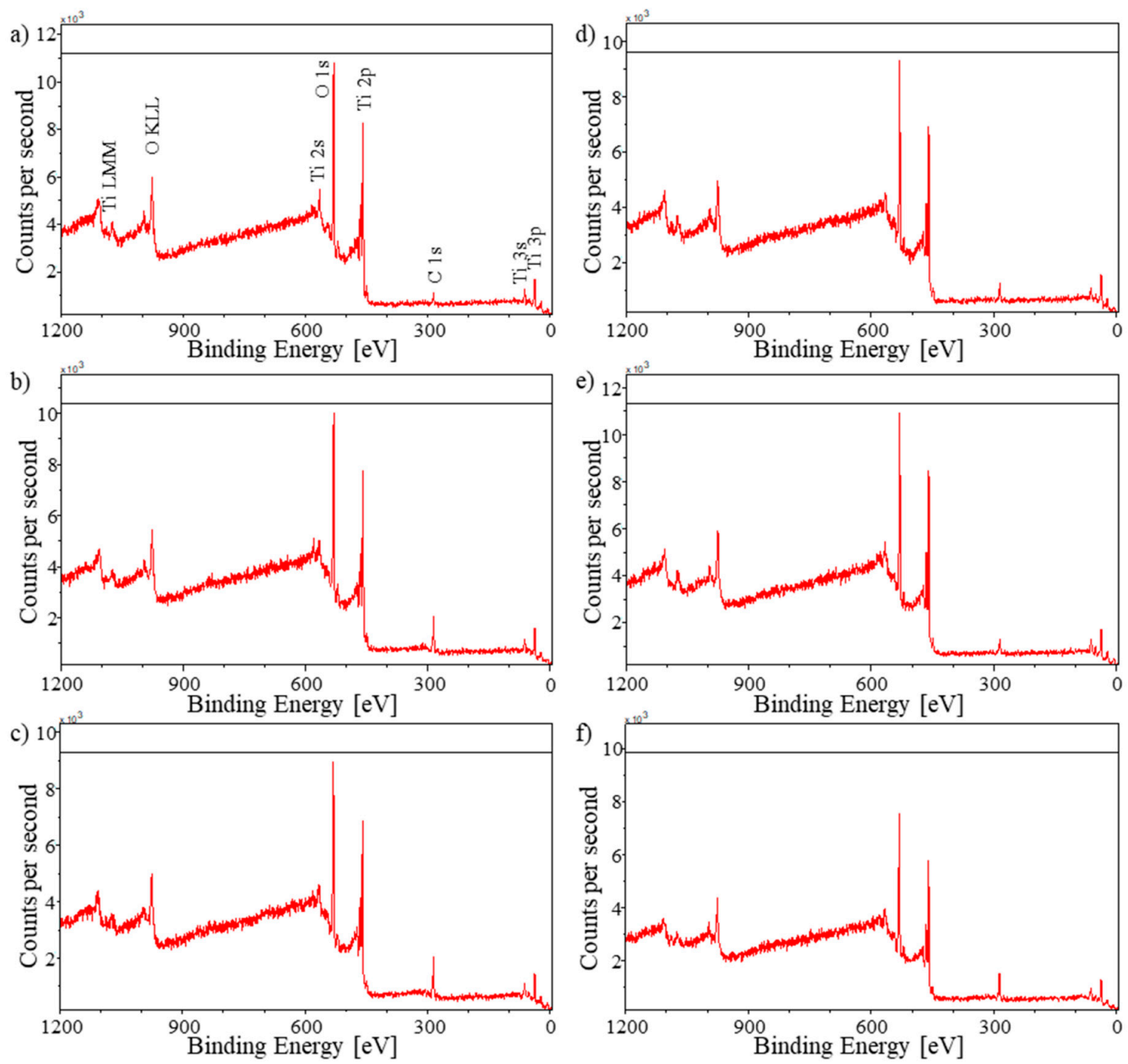

Figure 4. X-ray photoelectron spectra obtained for the materials: (a) $\mathrm{TiO}_{2} 5 \mathrm{~nm}$; (b) 1\%CuPc@TiO 5 nm; (c) 1\%ZnPc@TiO 5 nm; (d) $\mathrm{TiO}_{2} 15$ nm; (e) 1\%CuPc@TiO 15 nm; (f) 1\%ZnPc@TiO 15 nm.

\subsection{Particle Size}

The size of the particles was acquired using nanoparticle tracking analysis (NTA). The results are summarized in Table 2. The obtained particle sizes reveal that the materials were prone to agglomeration, which is strongly marked. The example size distribution of the NPs is shown in Figure 5. As a result of the agglomeration, none of the particles can be regarded as monodisperse. The polydispersity index of all the materials exceeds 0.2 [41]. 
Table 2. Particle size measured for $\mathrm{TiO}_{2}$ based materials.

\begin{tabular}{ccc}
\hline Material & Particle Size & Polydispersity Index $^{\text {a }}$ \\
\hline $\mathrm{TiO}_{2}(5 \mathrm{~nm})$ & $145.7 \pm 68.4 \mathrm{~nm}$ & 0.22 \\
\hline $1 \% \mathrm{CuPc} @ \mathrm{TiO}_{2}(5 \mathrm{~nm})$ & $103.5 \pm 87.8 \mathrm{~nm}$ & 0.72 \\
\hline $1 \% \mathrm{ZnPc} @ \mathrm{TiO}_{2}(5 \mathrm{~nm})$ & $158.7 \pm 74.4 \mathrm{~nm}$ & 0.22 \\
\hline $\mathrm{TiO}_{2}(15 \mathrm{~nm})$ & $201.6 \pm 139.8 \mathrm{~nm}$ & 0.48 \\
\hline $1 \% \mathrm{CuPc} @ \mathrm{TiO}_{2}(15 \mathrm{~nm})$ & $144.5 \pm 129.1 \mathrm{~nm}$ & 0.80 \\
\hline $1 \% \mathrm{ZnPc} @ \mathrm{TiO}_{2}(15 \mathrm{~nm})$ & $236.2 \pm 128.1 \mathrm{~nm}$ & 0.29 \\
\hline
\end{tabular}
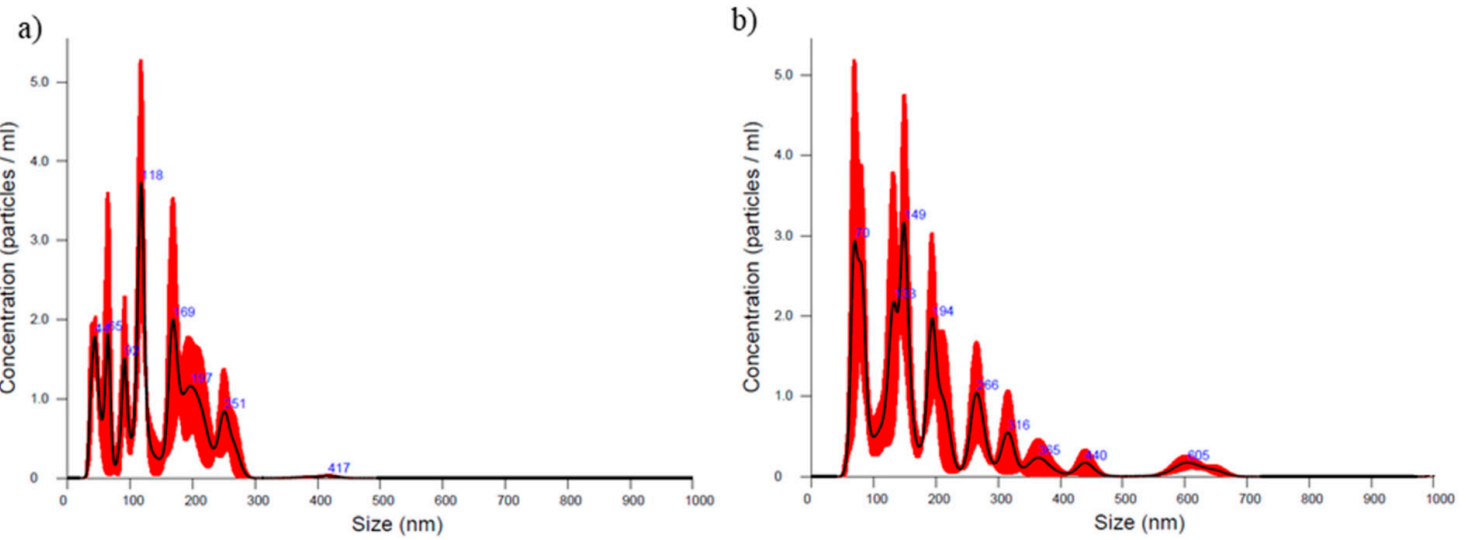

Figure 5. Particle size distribution patterns for (a) $\mathrm{TiO}_{2}(5 \mathrm{~nm})$ and $(\mathbf{b}) \mathrm{TiO}_{2}(15 \mathrm{~nm})$.

\subsection{Electron Spin Resonance Spectroscopy}

To check the effect of exposure on free radical generation in samples, the materials were also studied by ESR method. The exemplary ESR spectra are shown in Figure 6.
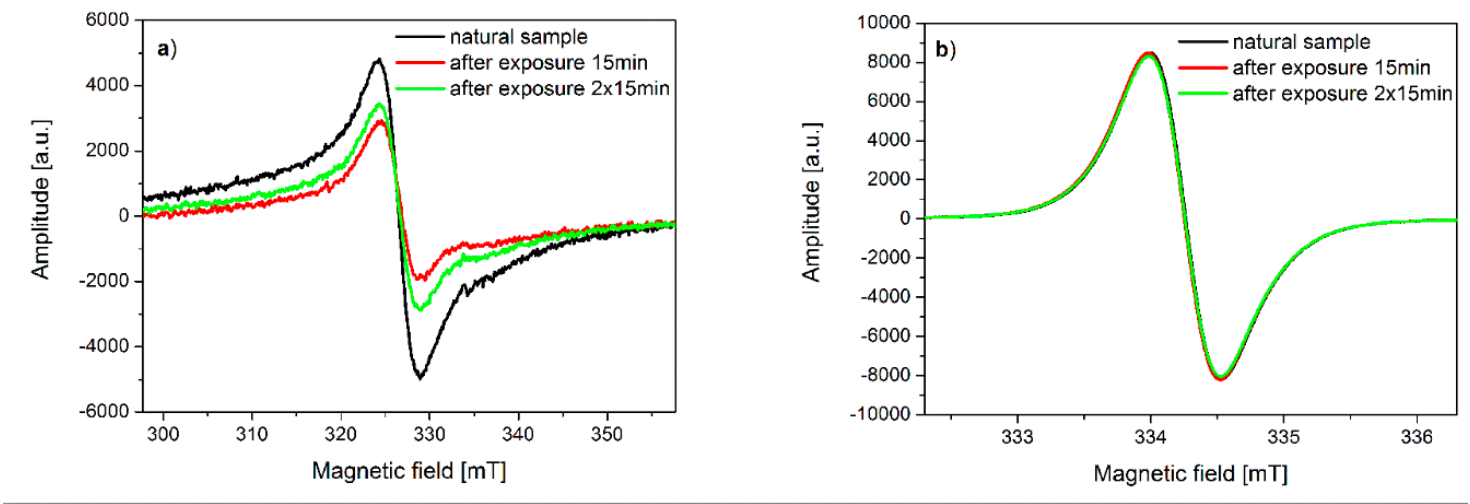

Figure 6. Exemplary electron spin resonance (ESR) spectra: (a) for $1 \% \mathrm{CuPc}_{\mathrm{CTiO}}(15 \mathrm{~nm})$ and (b) for $\mathrm{ZnPc}$.

For both types of samples, containing either zinc(II) or copper(II) phthalocyanine, a single line is visible. Typical spectroscopic parameters were determined: for zinc(II) phthalocyanine $\left(1 \% \mathrm{ZnPc} @ \mathrm{TiO}_{2}\right)$ $\mathrm{g}=2.0032, \Delta \mathrm{H}=0.75 \mathrm{mT}$ and for copper(II) phthalocyanine $\left(1 \% \mathrm{CuPc} @ \mathrm{TiO}_{2}\right) \mathrm{g}=2.0506, \Delta \mathrm{H}=4.67 \mathrm{mT}$. After the exposure to $665 \mathrm{~nm}$ light irradiation, the signal intensity changed, which means that the free radicals were generated. It seems that these changes depend on the time the material was irradiated: after 15 min the signal rapidly decreases and after another $15 \mathrm{~min}$ it increases but is still lower than 
non-irradiated sample (Figure 6a). Such changes were not observed for pure $\mathrm{ZnPc}$, for which the signal intensity was stable (Figure 6b). In the case of differently sized $\mathrm{TiO}_{2}$ nanoparticles it was observed that the non-irradiated sample with the particle size of $5 \mathrm{~nm}$ gave a very weak, trace signal. In contrast, the measurements of the sample of the larger particle size resulted in a complex signal, which decreased significantly after exposure. The observed changes in signal intensity are probably associated with the surface defects that are likely to promote the rapid recombination of generated free radicals. A thorough understanding of these changes and mechanisms that take place requires further study.

\subsection{BET Surface Area Analysis}

BET surface area analyses were performed for all the studied materials to assess whether the modification of titania with the phthalocyanines revealed any effect on the materials' surface. The results are summarized in Table 3.

Table 3. Brunauer-Emmett-Teller (BET) surface area measured for the materials prepared.

\begin{tabular}{cc}
\hline Material & BET Surface Area $\left[\mathbf{m}^{2} / \mathbf{g}\right]$ \\
\hline $\mathrm{TiO}_{2}(5 \mathrm{~nm})$ & $264.8 \pm 1.2$ \\
$1 \% \mathrm{CuPc} @ \mathrm{TiO}_{2}(5 \mathrm{~nm})$ & $249.7 \pm 1.5$ \\
$1 \% \mathrm{ZnPc} @ \mathrm{TiO}_{2}(5 \mathrm{~nm})$ & $244.3 \pm 1.5$ \\
\hline $\mathrm{TiO}_{2}(15 \mathrm{~nm})$ & $104.6 \pm 0.3$ \\
$1 \% \mathrm{CuPc} @ \mathrm{TiO}_{2}(15 \mathrm{~nm})$ & $96.8 \pm 0.3$ \\
$1 \% \mathrm{ZnPc} @ \mathrm{TiO}_{2}(15 \mathrm{~nm})$ & $100.4 \pm 0.3$ \\
\hline
\end{tabular}

The difference found in the surface areas between $5 \mathrm{~nm}$ and $15 \mathrm{~nm}$ materials is evident. The $5 \mathrm{~nm}$ nanoparticles exhibit a surface area of around $250 \mathrm{~m}^{2} / \mathrm{g}$, while the $15 \mathrm{~nm}$ ones present values close to $100 \mathrm{~m}^{2} / \mathrm{g}$. By comparing the data, the methodology used for the modification of both $\mathrm{TiO}_{2}$ materials with $1 \% \mathrm{CuPc}$ and $1 \% \mathrm{ZnPc}$ caused small decreases in the materials' surfaces, resulting from two factors. Firstly, the presence of phthalocyanines in titania nanoparticles pores. Secondly, the fact that the combination of nanoparticles with macrocycles can lead to an agglomeration of the received materials.

\subsection{Photochemical Studies}

\subsubsection{Photodegradation of Ibuprofen}

Ibuprofen is one of the most commonly used drugs in the world, for many years included in the WHO Model List of Essential Medicines [43]. Similar to other nonsteroidal anti-inflammatory drugs, it is used to treat pain, inflammation and to reduce fever both in adult and pediatric patients [44]. As an over-the-counter (OTC) drug with many indications, it is often taken without medical supervision [45]. Recent advances in analytical technology facilitate the detection of pharmaceutical compounds. The presence of ibuprofen in both wastewater influents and effluents has already been reported by numerous researchers [6,46-48]. The removal of ibuprofen or its metabolites in the course of the drinking water treatment process is not always efficient [49]. This raises concerns over potential risks to human health and aquatic ecosystems from exposure to ibuprofen traces in drinking water. The above considerations demonstrate that a modern, efficient technology ought to be applied for the removal of pharmaceuticals from water.

The photocatalytic systems based on $\mathrm{Pc}_{-}-\mathrm{TiO}_{2}$ or $\mathrm{TiO}_{2}$ nanoparticle suspension as photocatalysts were used for the assessment of ibuprofen removal from water via photodegradation process. To assess the photodegradation efficiency of both nanomaterials, IBU removal using $1 \% \mathrm{CuPc} @ \mathrm{TiO}_{2}$ and $1 \% \mathrm{ZnPc} @ \mathrm{TiO}_{2}$ with $\mathrm{TiO}_{2}$ alone was compared. It has been previously observed that using pure $\mathrm{TiO}_{2}$ it is possible to almost completely remove IBU in 2-3 h [50-53]. Furthermore, an approach was previously undertaken, where commercially available $\mathrm{P} 25 \mathrm{TiO}_{2}$ nanoparticles $(\sim 21 \mathrm{~nm})$ were used in 
combination with UV light to successfully degrade IBU [54]. What is more, the authors managed to identify a series of resulting IBU decomposition products. However, the authors did not use $\mathrm{TiO}_{2}$ based visible-light photocatalysts, only a neat $\mathrm{P} 25 \mathrm{TiO}_{2}$ and $\mathrm{UV}$ irradiation. It is worth noting, that the use of a sensitizing moiety was presented by Patterson et al., who used natural plant extracts to broaden the absorption spectrum of $\mathrm{P}_{25} \mathrm{TiO}_{2}$ [55]. The composites were used to form thin films and natural sunlight was tested as the light source, which allowed to double the efficacy of the photodegradation of IBU with neat P25 $\mathrm{TiO}_{2}$. In the herein presented study the solution of IBU in water was irradiated with the photocatalyst and accompanied by careful monitoring of the IBU concentration. The results are summarized in Figures 7 and 8.
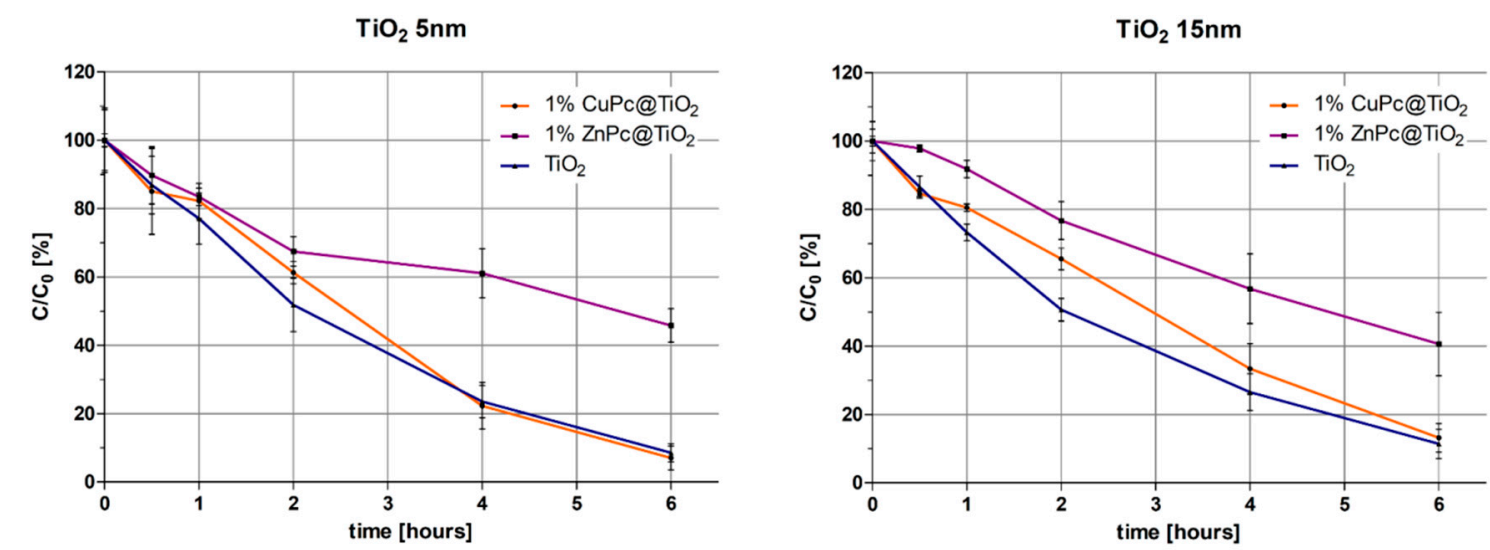

Figure 7. The changes in ibuprofen concentration after irradiation (365 nm light) of the solution containing a photocatalyst.
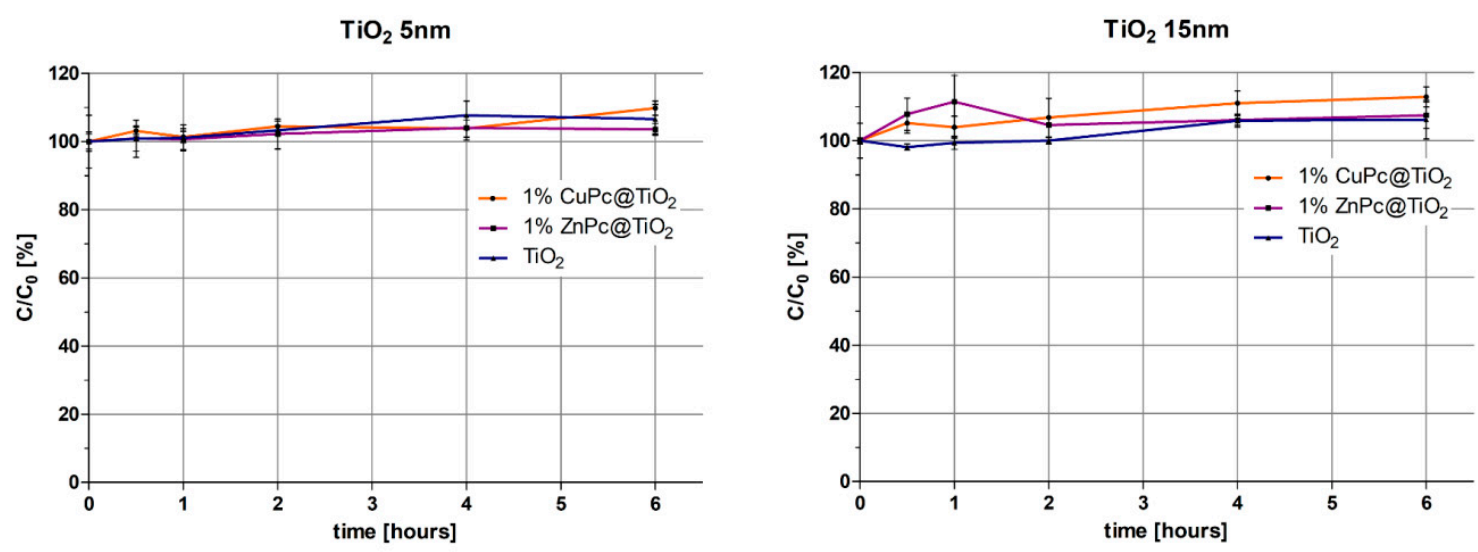

Figure 8. The changes in ibuprofen concentration after irradiation (665 nm light) of the solution containing a photocatalyst.

In contrast to the literature findings [53], after $2 \mathrm{~h}$ of our experiment, the levels of IBU were around $60 \%$ when referred to the IBU level at $\mathrm{t}_{0}$. In the case of UV-light driven photocatalytic degradation with $1 \% \mathrm{CuPc} @ \mathrm{TiO}_{2}$ and pure $\mathrm{TiO}_{2}$, almost complete removal of IBU was observed after six hours of our experiment. The use of the $665 \mathrm{~nm}$ red light did not cause any change in the IBU content in the tested experiments. Although one would expect such outcome in the case of neat $\mathrm{TiO}_{2}$ nanoparticles, $\mathrm{ZnPc}$ and CuPc grafted materials also did not yield any effect in these conditions despite the fact that both these phthalocyanines absorb the light at this wavelength. This is in contrast to the earlier literature reports, where $\mathrm{ZnPc}$ deposited on $\mathrm{P} 25 \mathrm{TiO}_{2}$ in an analogical manner was found photocatalytically active and enabled photodegradation of erythromycin [32]. Nevertheless, there are certain differences between the herein presented and the literature procedures. In our study the calcination step, following the Pc deposition on $\mathrm{TiO}_{2}$ nanoparticles, was omitted. It is believed that this step irrevocably leads to the decomposition of the phthalocyanine, as proven by the TGA measurements. Presumably, the material 
obtained before [32] was composed of $\mathrm{P}_{25} \mathrm{TiO}_{2}$ doped with $\mathrm{C}, \mathrm{N}$ or $\mathrm{Zn}$ on its surface with some residual phthalocyanine. Herein, in the presented study, probably due to the non-stabilized nature of the tested nanoparticles, only a portion of grafted macrocycles was present on the surface and could come in close proximity of IBU for the photocatalytic reaction to occur.

Although the factors mentioned above may have had the greatest impact on the result of the experiment, other differences will also be briefly discussed below. Factors such as the size and load of $\mathrm{TiO}_{2}$ particles, the initial IBU concentration, temperature were found to influence the photodegradation of IBU in aqueous solutions and have been explored in several studies [51]. Throughout our experiment the temperature did not exceed $35^{\circ} \mathrm{C}$, which seems to be consistent with other photocatalytic degradation research studies. As mentioned before, prior studies have also indicated the influence of the initial drug concentration on the process. The observed efficiency was usually increasing with the decrease of the initial concentration of IBU $[51,56]$. Additionally, the effect of the catalyst load has been reported in the literature. Several reports have shown that the optimal load of the suspended $\mathrm{TiO}_{2}$ is around $1000 \mathrm{mg} / \mathrm{L}$, however, these values typically varied between $50-3000 \mathrm{mg} / \mathrm{L}[50,51,54,56,57]$. Consistent with the literature, the initial IBU concentration in our study was $10 \mathrm{mg} / \mathrm{L}$, whereas the $\mathrm{TiO}_{2}$ load was $100 \mathrm{mg} / 0.1 \mathrm{~L}$. Hence, these parameters were expected to reveal similar degradation rates at similar sampling times. Another major factor, which could not be omitted, is the average particle size. In our experiment nano-grade $\mathrm{TiO}_{2}$ was used. Nano-scale particles have a higher surface-to-volume ratio than microparticles and thanks to the larger surface available for photocatalytic reactions, they are expected to be more efficient in the photodegradation studies. However, in the present study, the NPs tended to form agglomerates. Therefore, the access of IBU to the surface of the photocatalyst might have been limited, as it was suggested in other studies [51,58].

In the case of the UV irradiation experiments, another interesting fact was observed. Namely, the neat $\mathrm{TiO}_{2}$ was photocatalytically active to a similar extent as CuPc grafted titania, regardless of the nanoparticle size and the surface area presented by the nanomaterial. On the opposite, deposition of $\mathrm{ZnPc}$ on titanium(IV) oxide resulted in the decrease of IBU degradation rate in the case of both, $5 \mathrm{~nm}$ and $15 \mathrm{~nm}$ particles. This effect could be explained by the absorption of light by ZnPc deposited on the surface of $\mathrm{TiO}_{2}$ with the formation of Pc-derived reactive oxygen species, in particular very short-living singlet oxygen molecules. ZnPc is known to produce singlet oxygen, which would probably be dissipated before reaching IBU molecules [59]. In the case of CuPc, because of lower singlet oxygen generation quantum yields, the energy absorbed by the phthalocyanine had to be transferred to $\mathrm{TiO}_{2}$. In addition, the same results obtained for photocatalysts, regardless of the 5 or $15 \mathrm{~nm}$ particle size used, can be associated with the agglomeration of the non-stabilized nanoparticles [60]. As can be observed in Table 2., the measured mean sizes of the materials are much higher than those obtained for neat $\mathrm{TiO}_{2}$ nanoparticles and the wide-spread of the results is revealed by the high values of standard deviations. All these facts suggest that stabilization of the nanoparticles is necessary for the potential photocatalytic material.

\subsubsection{Calculation of Photodegradation Constants for Various Conditions Applied}

The kinetic parameters (degradation rate constants $k$ of IBU decay) were calculated for experiments with UV light irradiation and for the following series of photocatalysts: $1 \% \mathrm{ZnPc}_{\mathrm{TiO}}(5 \mathrm{~nm})$, $1 \% \mathrm{ZnPc} @ \mathrm{TiO}_{2}(15 \mathrm{~nm}), 1 \% \mathrm{CuPc} @ \mathrm{TiO}_{2}(5 \mathrm{~nm})$ 1\%CuPc@TiO $2(15 \mathrm{~nm}), \mathrm{TiO}_{2}(5 \mathrm{~nm})$ and $\mathrm{TiO}_{2}(15 \mathrm{~nm})$.

The results are depicted in Table 4. and in Figures 9 and 10. The studied reaction was defined as the first-order kinetics and the degradation rate constant was calculated using the formula (1):

$$
\ln P_{t}=\ln P_{0}-k \cdot t
$$

where: $P_{t}$ surface area of the sample in time $t[\mathrm{~h}]$ in the isothermal test, $P_{0}$ is the surface area of the sample in time 0 and $k\left[\mathrm{~s}^{-1}\right]$ is the reaction rate constant. According to the theory of first-order kinetics, the semi-logarithmic plot $P_{t}=f(t)$ is linear and its slope corresponds to the magnitude of the 
degradation rate constant $k$ (Figures 9 and 10). Thus, the least-squares method was used to calculate the regression parameters: $y=a x+b, a \pm \Delta a, b \pm \Delta b$, standard errors $S_{a}, S_{b}$ and the correlation coefficient $r$. The $\pm \Delta a, \pm \Delta b$ were estimated for $f=n-2$ degrees of freedom and $\alpha=0.05$. Table 4 . summarizes the results for each experiment.

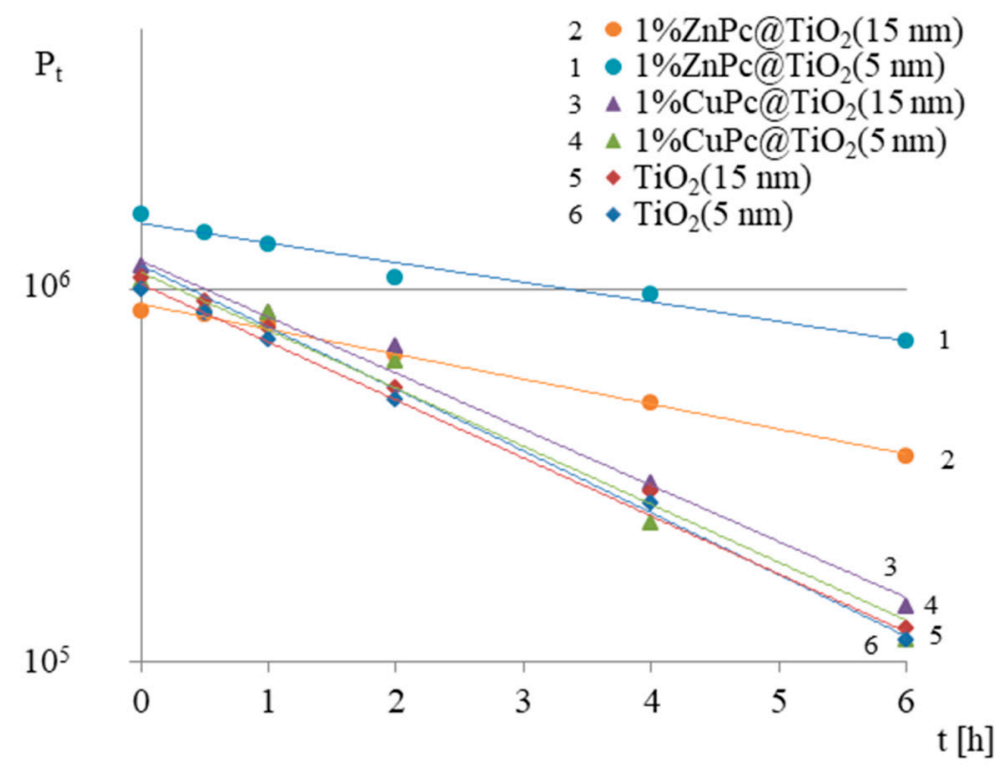

Figure 9. Comparison of ibuprofen (IBU) decomposition rates under UV irradiation with different photocatalysts.

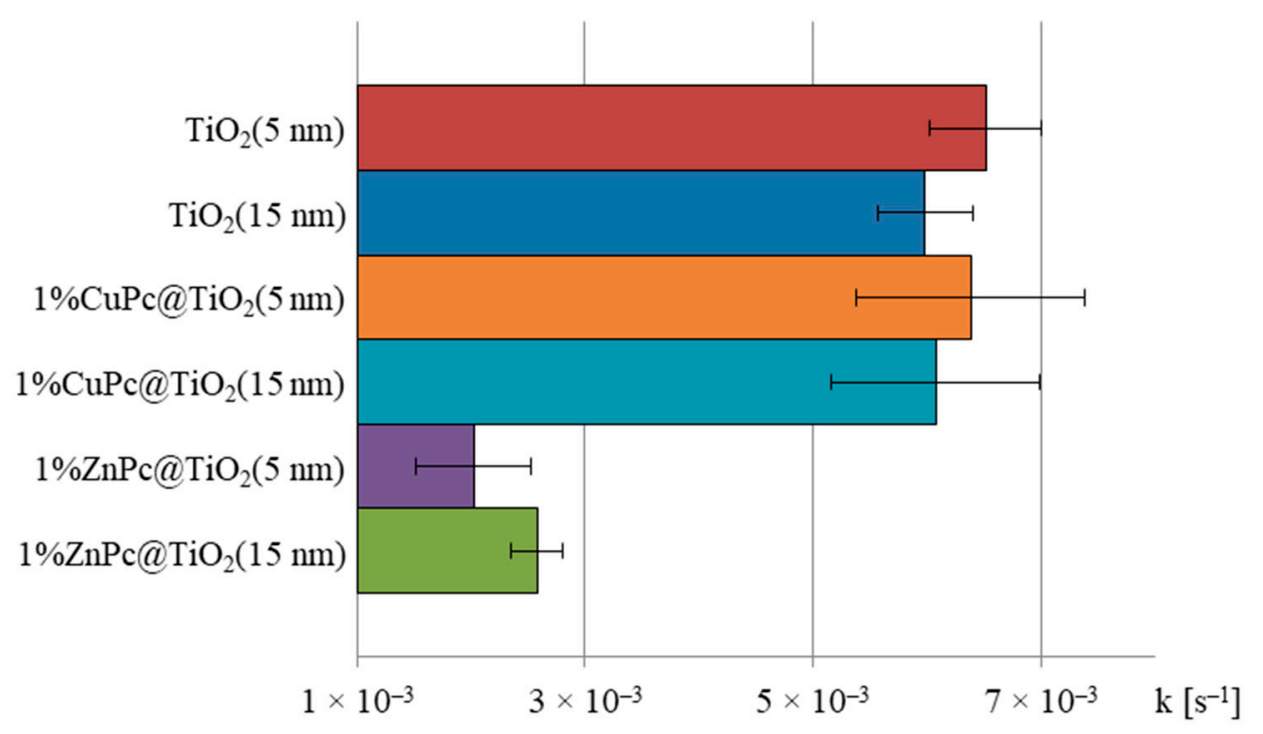

Figure 10. Comparison of degradation rate constants $\left(k, s^{-1}\right)$ of IBU under UV irradiation with different photocatalysts. 
Table 4. The regression and kinetic parameters of IBU degradation rate constants $\left(\mathrm{k}, \mathrm{s}^{-1}\right)$ under UV irradiation with 1\%ZnPc@TiO 2 (5 nm), 1\%ZnPc@TiO 2 (15 nm), 1\%CuPc@TiO 2 (5 nm) 1\%CuPc@TiO 2 $(15 \mathrm{~nm}), \mathrm{TiO}_{2}(5 \mathrm{~nm})$ and $\mathrm{TiO}_{2}(15 \mathrm{~nm})$ as a photocatalysts.

\begin{tabular}{|c|c|c|c|c|c|}
\hline Samples & \multicolumn{2}{|c|}{ Regression Parameters ${ }^{a}$} & \multicolumn{3}{|c|}{ Kinetic Parameters $\left[k\left(s^{-1}\right)\right]^{b}$} \\
\hline \multirow{8}{*}{ 1\%ZnPc@TiO 2 (5 nm) } & a & -0.1214 & $\mathrm{k}$ & $2.024 \times 10^{-3}$ & $\mathrm{~s}^{-1}$ \\
\hline & $\Delta \alpha$ & 0.0303 & $\Delta \kappa$ & $5.051 \times 10^{-4}$ & $\mathrm{~s}^{-1}$ \\
\hline & $b=y(0)$ & 1504745.2 & & & \\
\hline & $\Delta \beta$ & 1.098 & & & \\
\hline & sa & 0.0117 & & & \\
\hline & $\mathrm{sb}$ & 0.0364 & & & \\
\hline & sy & 0.0611 & & & \\
\hline & $\mathrm{r}$ & -0.982 & & & \\
\hline \multirow{8}{*}{ 1\%ZnPc@TiO 2 (15 nm) } & $\mathrm{a}$ & -0.1548 & $\mathrm{k}$ & $2.580 \times 10^{-3}$ & $\mathrm{~s}^{-1}$ \\
\hline & $\Delta \alpha$ & 0.0136 & $\Delta \kappa$ & $2.279 \times 10^{-4}$ & $\mathrm{~s}^{-1}$ \\
\hline & $\mathrm{b}=\mathrm{y}(0)$ & 912073.1 & & & \\
\hline & $\Delta \beta$ & 1.043 & & & \\
\hline & sa & 0.00531 & & & \\
\hline & $\mathrm{sb}$ & 0.0164 & & & \\
\hline & sy & 0.02757 & & & \\
\hline & $\mathrm{r}$ & -0.998 & & & \\
\hline \multirow{8}{*}{ 1\%CuPc@TiO 2 (5 nm) } & a & -0.3832 & $\mathrm{k}$ & $6.387 \times 10^{-3}$ & $\mathrm{~s}^{-1}$ \\
\hline & $\Delta \alpha$ & 0.0601 & $\Delta \kappa$ & $1.002 \times 10^{-3}$ & $\mathrm{~s}^{-1}$ \\
\hline & $\mathrm{b}=\mathrm{y}(0)$ & 1160993.9 & & & \\
\hline & $\Delta \beta$ & 1.204 & & & \\
\hline & sa & 0.0233 & & & \\
\hline & $\mathrm{sb}$ & 0.0722 & & & \\
\hline & sy & 0.121 & & & \\
\hline & $\mathrm{r}$ & -0.993 & & & \\
\hline \multirow{8}{*}{ 1\%CuPc@TiO 2 (15 nm) } & a & -0.3649 & $\mathrm{k}$ & $6.083 \times 10^{-3}$ & $\mathrm{~s}^{-1}$ \\
\hline & $\Delta \alpha$ & 0.0548 & $\Delta \kappa$ & $9.149 \times 10^{-4}$ & $\mathrm{~s}^{-1}$ \\
\hline & $\mathrm{b}=\mathrm{y}(0)$ & 1242276.5 & & & \\
\hline & $\Delta \beta$ & 1.184 & & & \\
\hline & sa & 0.0213 & & & \\
\hline & $\mathrm{sb}$ & 0.0659 & & & \\
\hline & sy & 0.11 & & & \\
\hline & $\mathrm{r}$ & -0.993 & & & \\
\hline \multirow{8}{*}{$\mathrm{TiO}_{2}(5 \mathrm{~nm})$} & a & -0.391 & $\mathrm{k}$ & $6.517 \times 10^{-3}$ & $\mathrm{~s}^{-1}$ \\
\hline & $\Delta \alpha$ & 0.0292 & $\Delta \kappa$ & $4.876 \times 10^{-4}$ & $\mathrm{~s}^{-1}$ \\
\hline & $\mathrm{b}=\mathrm{y}(0)$ & 1158957.5 & & & \\
\hline & $\Delta \beta$ & 1.0945 & & & \\
\hline & sa & 0.011381 & & & \\
\hline & $\mathrm{sb}$ & 0.0351 & & & \\
\hline & sy & 0.0589 & & & \\
\hline & $\mathrm{r}$ & -0.998 & & & \\
\hline \multirow{8}{*}{$\mathrm{TiO}_{2}(15 \mathrm{~nm})$} & $\mathrm{a}$ & -0.359 & $\mathrm{k}$ & $5.988 \times 10^{-3}$ & $\mathrm{~s}^{-1}$ \\
\hline & $\Delta \alpha$ & 0.0252 & $\Delta \kappa$ & $4.202 \times 10^{-4}$ & $\mathrm{~s}^{-1}$ \\
\hline & $\mathrm{b}=\mathrm{y}(0)$ & 1111784.1 & & & \\
\hline & $\Delta \beta$ & 1.08 & & & \\
\hline & sa & 0.0098 & & & \\
\hline & $\mathrm{sb}$ & 0.0302 & & & \\
\hline & sy & 0.0508 & & & \\
\hline & $\mathrm{r}$ & -0.999 & & & \\
\hline
\end{tabular}

a The parameters: $a, s a, b, s b$ and $r$ were calculated by the least square regression and stand for slope, the standard deviation of the slope, intercept, the standard deviation of intercept and correlation coefficient, respectively. $\mathrm{b}$ The kinetic parameters $\left.\mathrm{k}^{-1} \mathrm{~s}^{-1}\right]$ is the photodegradation reaction of IBU constant rate.

\subsection{Acute Toxicity Assessment}

The solutions of ibuprofen were subjected to ecotoxicity testing using the Microtox ${ }^{\circledR}$ test. The test is based on Aliivibrio fischeri bacterial cell suspension. The changes in bioluminescence after a sample is added can be directly correlated with the metabolism of the bacteria. So that the luminescence 
decreases linearly with the sample toxicity increase [61,62]. As can be seen in Figure 11a, the toxicity of the ibuprofen solutions photoremediated with UV light slightly increases in comparison with IBU solutions before the irradiation. Since ibuprofen is oxidized to other products which might express higher toxicity, these results can be associated with degradation of IBU to its photoproducts [63].

a)

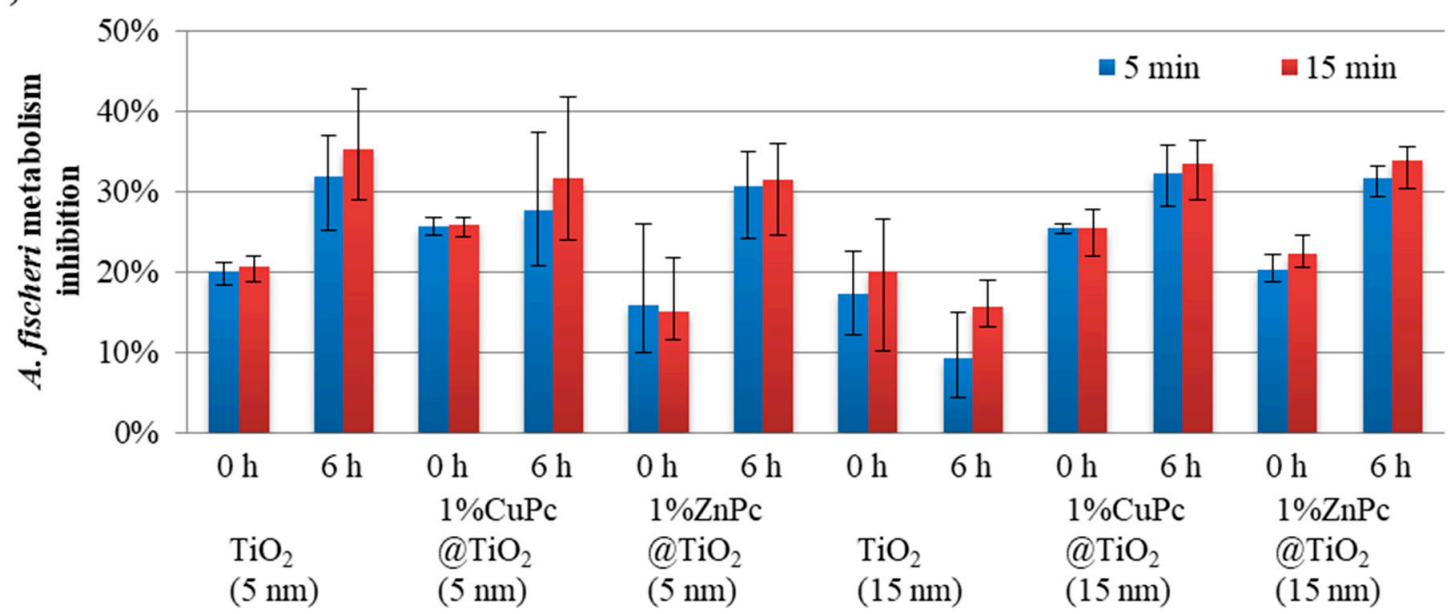

b)

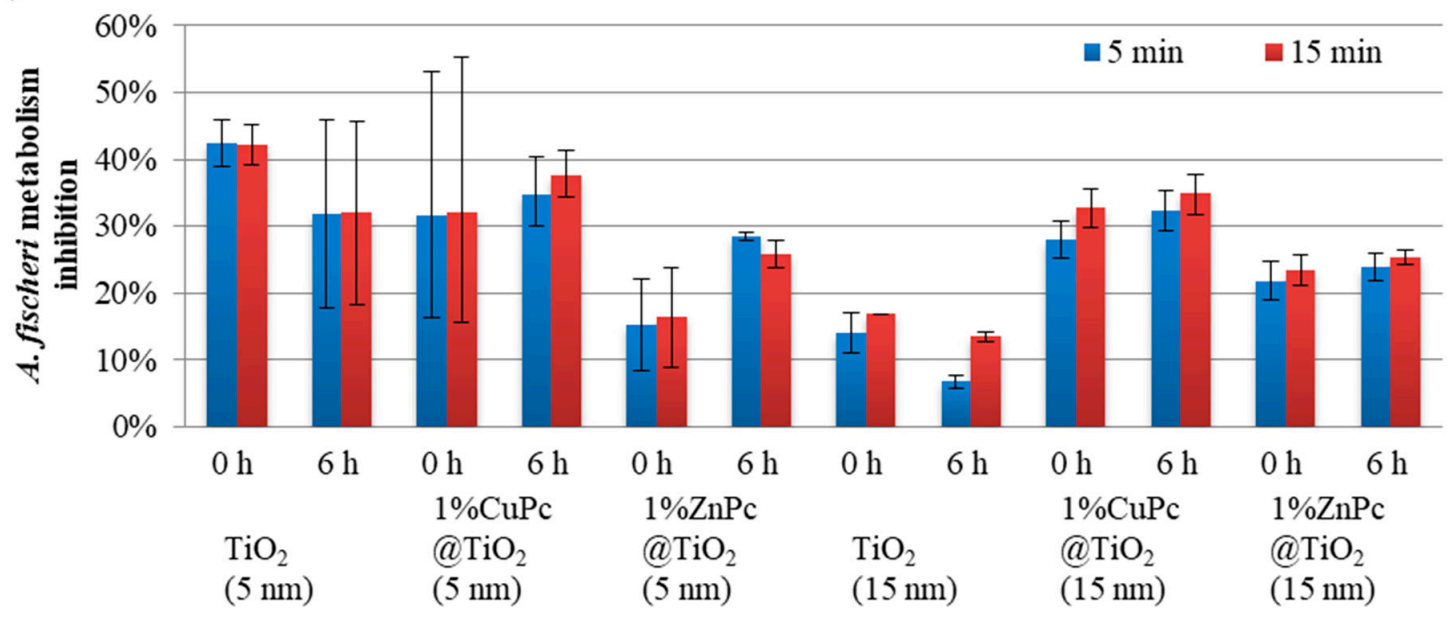

Figure 11. Cell viability decrease of $A$. fischeri cells upon addition of ibuprofen solutions before $(0 \mathrm{~h})$ and after $(6 \mathrm{~h})$ photodegradation experiment with different photocatalysts, when irradiated with (a) UV $\operatorname{light}\left(\lambda_{\max }=365 \mathrm{~nm}\right),(\mathbf{b})$ red light $\left(\lambda_{\max }=665 \mathrm{~nm}\right)$.

As can be seen in Figure 11b, the solutions photocatalyzed with red light by neat $\mathrm{TiO}_{2}$ nanoparticles exhibit unchanged toxicity to $A$. fischeri bacteria. In case of phthalocyanine-grafted titania nanoparticles, despite the UV or red light irradiation, the toxicities of both solutions are comparable. A slight ca. $10 \%$ toxicity increase of the ibuprofen irradiated solutions after $6 \mathrm{~h}$ of the UV light irradiation was noted. In addition, this effect was weaker for $\mathrm{Pc}_{\mathrm{C}} \mathrm{TiO}_{2}(15 \mathrm{~nm})$ than for $\mathrm{Pc}_{\mathrm{TiO}}(5 \mathrm{~nm})$. It indicates that thephotocatalytic activity of anatase is potentiated with the use of proper modification of titania nanoparticles.

\section{Materials and Methods}

\subsection{Materials and Instruments}

All reaction mixtures were stirred using Radleys Heat-On ${ }^{\mathrm{TM}}$ heating system (Saffron Walden, United Kingdom). Solvents and all reagents were obtained from commercial suppliers (Merck, 
Darmstadt, Germany; Fluorochem, Hadfield, United Kingdom; Chempur, Piekary Ślaskie, Poland; Avantor Performance Materials Poland S.A., Gliwice, Poland) and used without further purification. $\mathrm{TiO}_{2}$ anatase nanoparticles were purchased from US Research Nanomaterials Inc., Houston, TX, USA.

Mass spectrometry-grade methanol and ammonium acetate were purchased from Sigma-Aldrich (Saint Louis, MO, USA). Mass spectrometry-grade water was prepared by reverse osmosis in a Demiwa system from Watek (Ledec nad Sazavou, Czech Republic), followed by double distillation from a quartz apparatus.

\subsection{Preparation of Nanoparticles}

$\mathrm{TiO}_{2}-\mathrm{Pc}$ nanoparticles were prepared as a modification of chemical deposition method [64]. As an example, for the preparation of $1 \% \mathrm{ZnPc}_{\mathrm{T}} \mathrm{TiO}_{2}$ material, zinc(II) phthalocyanine $(10 \mathrm{mg}, 0.017 \mathrm{mmol})$ was dissolved in analytical grade dichloromethane in a round-bottom flask. Titanium dioxide $(1000 \mathrm{mg})$ of appropriate particle size was added and the suspension was sonicated for $0.5 \mathrm{~h}$ and then stirred for 1 hour. After that, the solvent was removed using a rotary evaporator. The resulting blue powder was dried in air for $10 \mathrm{~h}$ to remove any traces of the solvent.

For the means of comparison, pure $\mathrm{TiO}_{2}$ was treated according to the same procedure but without the addition of the macrocycle.

\subsection{Nanoparticle Characterization}

\subsubsection{Thermogravimetric Analysis}

Thermogravimetric analysis was performed at the Wielkopolska Center for Advanced Technologies in Poznań, Poland, with the use of a thermogravimetric analyzer (TGA 4000, Perkin Elmer, Kraków, Poland). The analyzed materials were: $\mathrm{TiO}_{2}(5 \mathrm{~nm}), \mathrm{TiO}_{2}(15 \mathrm{~nm})$, neat $\mathrm{ZnPc}$, neat $\mathrm{CuPc}$ and $\mathrm{Pc}_{\mathrm{T}} \mathrm{TiO}{ }_{2}$ composites. Samples of around $5 \mathrm{mg}$ were heated from room temperature to $900{ }^{\circ} \mathrm{C}$ at the speed of $10{ }^{\circ} \mathrm{C} / \mathrm{min}$. The experiments were conducted in a nitrogen atmosphere. Temperature measurements were accurate up to $10^{-5}{ }^{\circ} \mathrm{C}$, while the masses with the accuracy of $10^{-5} \mathrm{mg}$.

\subsubsection{X-ray Powder Diffraction}

X-ray diffraction patterns of the samples were recorded at the Poznan University of Medical Sciences Core Facility on a Bruker AXS D2 Phaser diffractometer (Bruker AXS GmbH, Karlsruhe, Germany) with a $\mathrm{Cu} \mathrm{K} \alpha$ anode $(\lambda=1.54060 \AA$ ) operating at $30 \mathrm{kV}$ and $10 \mathrm{~mA}$. The diffraction patterns were collected at ambient temperature over an angular measurement range of $5^{\circ}$ to $60^{\circ} 2 \theta$ with a step size of $0.02^{\circ}$ and a counting rate of $2 \mathrm{~s} / \mathrm{step}$ with the sample spinning.

\subsubsection{X-ray Photoelectron Spectroscopy}

X-ray photoelectron spectroscopy (XPS) experiments were performed under $10^{-9}$ mbar vacuum using SPECS Multimethod system with XPS, SPECS Surface Nano Analysis GmbH (Berlin, Germany). $\mathrm{Al}$ anode was used as the source of non-monochromatic X-rays. CasaXPS software was used to analyze the data.

\subsubsection{Particle Size}

The nanoparticle size distribution was analyzed using Malvern Panalytical (Malvern, United Kingdom) NanoSight LM10 instrument (sCMOS camera, $405 \mathrm{~nm}$ laser) using NTA (Nanoparticle Tracking Analysis) 3.2 Dev Build 3.2.16 software. Before the measurements, the NP dispersions were diluted with water to achieve the operating range of nanoparticle concentration. The temperature of the sample chamber was set and maintained at $25.0 \pm 0.1^{\circ} \mathrm{C}$ and the syringe pump infusion rate was set to 200. For each sample, three movies of 30 seconds in length were recorded. 


\subsubsection{Electron Spin Resonance Spectroscopy}

All samples were studied using ESR spectroscopy. The measurements were carried out on an X-band Bruker EMX-10 spectrometer (Bruker, Billerica, MA, USA) with a magnetic field second modulation frequency of $100 \mathrm{kHz}$. The ESR spectra were recorded at room temperature $(293 \mathrm{~K})$ in two magnetic field ranges: $60 \mathrm{mT}$ or $4 \mathrm{mT}$. Each sample was measured three times: before exposure, after exposure for $15 \mathrm{~min}$ and after subsequent exposure for another $15 \mathrm{~min}$. Typical spectroscopic parameters: g-factor value, peak-to-peak line width $(\Delta \mathrm{H})$ and ESR signal intensity (corresponding to the concentration of free radicals in the sample) were determined for ESR spectra.

\subsubsection{BET Surface Area Analysis}

The Brunauer-Emmet-Teller surface area analysis was performed at the Wielkopolska Center for Advanced Technologies in Poznań, Poland, with the use of ASAPта 2420 system (Micromeritics $®$, Norcross, GA, USA).

\subsection{Photochemical Studies}

\subsubsection{Set-Up of the Photocatalytic Experiment}

The source of light in the irradiation experiments was a set of three laser diodes with $\lambda_{\max }=665 \mathrm{~nm}$ for the red light irradiation or $\lambda_{\max }=365 \mathrm{~nm}$ for UV irradiation. Light intensity was set to $20 \mathrm{~mW} / \mathrm{cm}^{2}$ and monitored with a $R D$ 0.2/2 radiometer (Optel, Wrocław, Poland). Distilled water was used in all experiments.

The photodegradation experiment was carried out in a reactor, which consisted of three beakers placed on a magnetic stirrer in the middle and three UV-Vis lamps with peak emission wavelength of either $365 \mathrm{~nm}$ or $665 \mathrm{~nm}$, positioned on a circular line (Figure 12). A layer of aluminum foil was placed behind and above the photoreactor to prevent scattering of light or heat energy and to protect the operator. To each of the beakers containing $100 \mathrm{~mL}$ of IBU solution at concentration $10 \mathrm{mg} / \mathrm{L}, 100 \mathrm{mg}$ of $\mathrm{TiO}_{2}$-based material was added, sonicated for about 1 minute and stirred vigorously in the dark for $30 \mathrm{~min}$. After that, LED lamps (either UV or Vis) were turned on and the mixtures were irradiated for $6 \mathrm{~h}$ while being constantly stirred. Samples $(\sim 2 \mathrm{~mL})$ were taken at time-points: $-0.5 \mathrm{~h}, 0 \mathrm{~h}, 0.5 \mathrm{~h}$, $1.0 \mathrm{~h}, 2.0 \mathrm{~h}, 4.0 \mathrm{~h}, 6.0 \mathrm{~h}$ after the irradiation was started. The temperature of the solution during the photocatalytic reaction did not exceed $35^{\circ} \mathrm{C}$.

a)

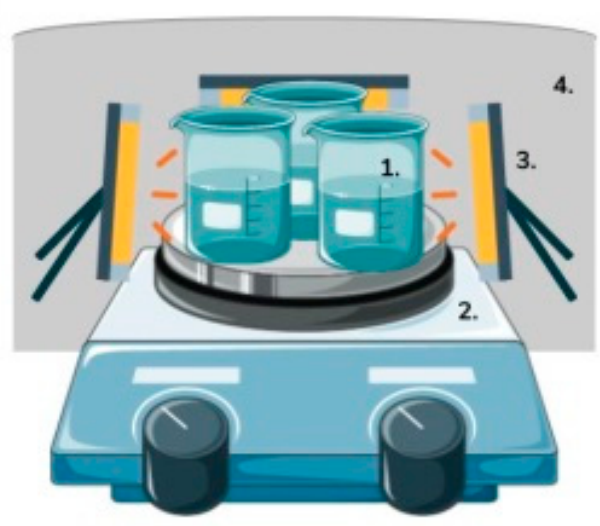

b)

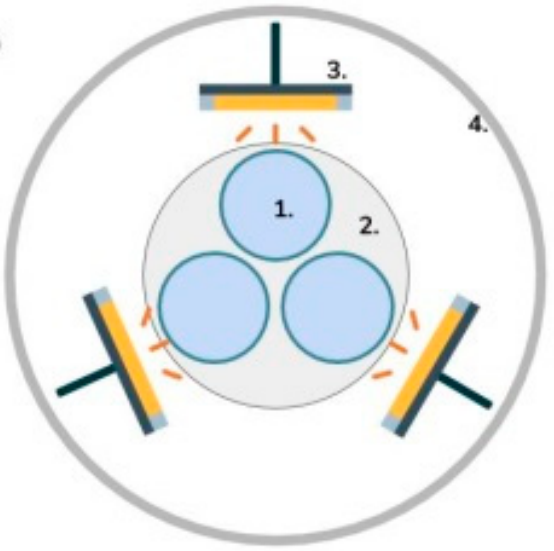

Figure 12. Setup of the photodegradation experiment (a) as seen from the front and (b) as seen from the above. 1. Beaker containing $100 \mathrm{mg}$ of $\mathrm{Pc}_{\mathrm{CTiO}}$ and $100 \mathrm{~mL}$ of IBU solution; 2. magnetic stirrer; 3. UV or Vis lamp; 4. aluminum foil.

Collected samples were centrifuged (10000 rpm, $30 \mathrm{~min}$ ) and the supernatant was filtered through $0.2 \mu \mathrm{m}$ poly(tetrafluoroethylene) (PTFE) syringe filters. Before the liquid chromatography coupled to 
mass spectrometry (LC-MS/MS) analysis the samples were diluted 20 times in a methanol/water 1:1 $(\mathrm{v} / \mathrm{v})$ mixture.

\subsubsection{LC-MS/MS Analysis of the Samples}

A chromatographic system UltiMate 3000 RSLC from Dionex (Sunnyvale, CA, USA) coupled with the API 4000 QTRAP triple quadrupole mass spectrometer from AB Sciex (Foster City, CA, USA) was used and $5 \mu \mathrm{L}$ samples were injected into a Synergi Fusion- $R P$ column $(50 \mathrm{~mm} \times 2.0 \mathrm{~mm}$ I.D.; $2,5 \mu \mathrm{m}$ ) from Phenomenex (Torrance, CA, USA) maintained at $35^{\circ} \mathrm{C}$. The mobile phase employed in the analysis consisted of $5 \times 10^{-3} \mathrm{~mol} \mathrm{~L}^{-1}$ ammonium acetate in water and methanol at a flow rate

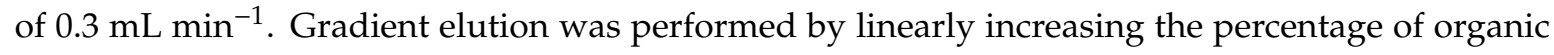
modifier from 70 to $100 \%$ in $2.5 \mathrm{~min}$ and then holding it at $100 \%$ to $3 \mathrm{~min}$. A pre-run time of $3 \mathrm{~min}$ was used before the next injection. The effluent from the LC column was introduced into the electrospray ionization source (Turbo Ion Spray) operated in negative ion mode. The following settings were used for the ion source and mass spectrometer-curtain gas 10 psi, nebulizer gas 40 psi, auxiliary gas 40 psi, temperature $400{ }^{\circ} \mathrm{C}$, ion spray voltage $-3500 \mathrm{~V}$, declustering potential $-35 \mathrm{~V}$ and collision gas set to medium. The dwell time for mass transition detected in the reaction monitoring mode was set to $100 \mathrm{~ms}$. The quantitative transition was from 205 to $161 \mathrm{~m} / \mathrm{z}$ at collision energy set to $-10 \mathrm{eV}$.

The linearity of the method was tested in a range of $2-1000\left[\mu \mathrm{g} \mathrm{L}^{-1}\right]$. The instrumental limit of detection (LOD) and the instrumental limit of quantitation (LOQ) were calculated on the basis of signal to noise $(\mathrm{S} / \mathrm{N})$ ratio. The $\mathrm{S} / \mathrm{N}=3$ was used for calculation of $\mathrm{LOD}$ and the $\mathrm{S} / \mathrm{N}=10$ for calculation of LOQ. Precision and accuracy were not tested because sample preparation included only a dilution step. Therefore, only the injection precision of the instrument applies in this procedure, which was always below $1 \%$. For ibuprofen $\mathrm{LOD}=0.5\left[\mu \mathrm{g} \mathrm{L}^{-1}\right], \mathrm{LOQ}=1.7\left[\mu \mathrm{g} \mathrm{L}^{-1}\right]$.

\subsection{Microtox ${ }^{\circledR}$ Acute Toxicity Assessment}

The samples of the remediated solutions were tested using Microtox ${ }^{\circledR}$ acute toxicity test- $81.9 \%$ Screening Test which was performed using Microtox ${ }^{\circledR}$ M500 equipment, according to the protocols distributed by the producer (ModernWater plc, London, United Kingdom) [61,65]. Cell viability was calculated according to bioluminescence emitted by the Aliivibrio fischeri bacteria as measured with Microtox ${ }^{\circledR}$ M500 with Modern Water MicrotoxOmni 4.2 software.

\section{Conclusions}

To sum up, materials based on pure anatase titania nanoparticles and phthalocyanines were prepared by a chemical deposition method, as well as carefully analyzed by TGA, XRPD, XPS, particle size measurements and ESR. The analytical techniques revealed that the applied $\mathrm{TiO}_{2}$ modification method was suitable because of having no effect on anatase crystallographic phase. As exhibited in ESR measurements, the materials were able to generate free radicals and their formation changed upon red-light exposure. As the materials were found to agglomerate, proper stabilization of the nanoparticles will be considered in our further studies.

The experiments with ibuprofen aqueous solutions indicated that the best results can be obtained after UV light irradiation. CuPc doped $\mathrm{TiO}_{2}$ was found to be as effective as neat $\mathrm{TiO}_{2}$ when exposed to $365 \mathrm{~nm}$ light, whilst the $\mathrm{ZnPc}$ modified titania was shown to photocatalyze the degradation of ibuprofen at a slower rate. The experiments performed using the modified titania and red light at $665 \mathrm{~nm}$ demonstrated the lack of effectiveness of the obtained materials, as well as neat $\mathrm{TiO}_{2}$, in these conditions. The acute toxicity assessment showed only a slight increase in toxicity of the ibuprofen solutions after the photodegradation experiment in the presence of modified $\mathrm{TiO}_{2}$ nanoparticles. The results show that the use of such approach does not impede the excellent photocatalytic activity of anatase and it might be potentiated with the use of proper modification of titania nanoparticles in the form of robust molecules preventing agglomeration or the use of surfactants. 
Author Contributions: Conceptualization: T.G., B.J.S., A.Z.-G., R.B., R.K. (Ryszard Krzyminiewski) and M.S. (Marek Sikorski); methodology: R.K. (Rafal Krakowiak), J.M. (Joanna Musial), R.F., J.M. (Jadwiga Mielcarek), B.D., W.B.-B. and D.T.M.; software: W.B.-B. and E.T.; validation: J.M. (Joanna Musial), R.F., A.Z.-G. and B.J.S.; formal analysis: J.M. (Joanna Musial), R.F., J.M. (Jadwiga Mielcarek), B.D., W.B.-B., A.Z.-G., B.J.S., D.T.M.; investigation: R.K. (Rafal Krakowiak), J.M. (Joanna Musial), R.F., M.S. (Marcin Spychala), J.M. (Jadwiga Mielcarek), B.D., W.B.-B., A.Z.-G., D.T.M.; resources: R.K. (Ryszard Krzyminiewski), E.T., R.B., A.Z.-G., B.J.S., T.G.; data curation: R.K. (Rafal Krakowiak), J.M. (Joanna Musial), J.M. (Jadwiga Mielcarek), B.D., W.B.-B., A.Z.-G., B.J.S., T.G., D.T.M; writing—original draft preparation: Ra.K., J.Mu., M.Sp., J.Mi., B.D., A.Z.-G., B.J.S., D.T.M.; writing一review and editing: R.K. (Rafal Krakowiak), J.M. (Joanna Musial), J.M. (Jadwiga Mielcarek), M.S. (Marek Sikorski), E.T., B.J.S., T.G., D.T.M.; visualization: R.K. (Rafal Krakowiak), J.M. (Joanna Musial), B.D., A.Z.-G., B.J.S.; supervision: T.G., R.B., E.T., R.K. (Ryszard Krzyminiewski); project administration: T.G.; funding acquisition: T.G. All authors have read and agreed to the published version of the manuscript.

Funding: This research was funded by the National Science Centre, Poland, grant number 2016/21/B/NZ9/00783.

Acknowledgments: The authors would like to acknowledge Poznan University of Medical Sciences Core Facility for providing access to D2 PHASER diffractometer. The authors thank Beata Kwiatkowska and Rita Kuba for excellent technical assistance. DTM would like to thank Agata Kaluzna-Mlynarczyk for her support. The authors acknowledge the preliminary experiments by Anna Bordzio.

Conflicts of Interest: The funders had no role in the design of the study; in the collection, analyses or interpretation of data; in the writing of the manuscript or in the decision to publish the results.

\section{References}

1. Ling, S.D.; Davey, A.; Reeves, S.E.; Gaylard, S.; Davies, P.L.; Stuart-Smith, R.D.; Edgar, G.J. Pollution signature for temperate reef biodiversity is short and simple. Mar. Pollut. Bull. 2018, 130, 159-169. [CrossRef] [PubMed]

2. Wang, Q.; Yang, Z. Industrial water pollution, water environment treatment and health risks in China. Environ. Pollut. 2016, 218, 358-365. [CrossRef] [PubMed]

3. La Farré, M.; Pérez, S.; Kantiani, L.; Barceló, D. Fate and toxicity of emerging pollutants, their metabolites and transformation products in the aquatic environment. TrAC Trends Anal. Chem. 2008, 27, 991-1007. [CrossRef]

4. Candido, J.P.; Andrade, S.J.; Fonseca, A.L.; Silva, F.S.; Silva, M.R.A.; Kondo, M.M. Ibuprofen removal by heterogeneous photocatalysis and ecotoxicological evaluation of the treated solutions. Environ. Sci. Pollut. Res. 2016, 23, 19911-19920. [CrossRef] [PubMed]

5. Carvalho, A.; Mestre, A.; Andrade, M.; Ania, C. Ibuprofen in the Aquatic Environment: Occurrence, Ecotoxicity and Water Remediation Technologies. In Ibuprofen: Clinical Pharmacology, Medical Uses and Adverse Effects; Nova Science Pub Inc.: Hauppauge, NY, USA, 2013; pp. 1-84. ISBN 978-1-62618-659-0.

6. Kostich, M.S.; Batt, A.L.; Lazorchak, J.M. Concentrations of prioritized pharmaceuticals in effluents from 50 large wastewater treatment plants in the US and implications for risk estimation. Environ. Pollut. 2014, 184, 354-359. [CrossRef]

7. Gadipelly, C.; Pérez-González, A.; Yadav, G.D.; Ortiz, I.; Ibáñez, R.; Rathod, V.K.; Marathe, K.V. Pharmaceutical Industry Wastewater: Review of the Technologies for Water Treatment and Reuse. Ind. Eng. Chem. Res. 2014, 53, 11571-11592. [CrossRef]

8. Majumder, A.; Gupta, B.; Gupta, A.K. Pharmaceutically active compounds in aqueous environment: A status, toxicity and insights of remediation. Environ. Res. 2019, 176, 108542. [CrossRef]

9. Godoy, A.A.; Kummrow, F.; Pamplin, P.A.Z. Occurrence, ecotoxicological effects and risk assessment of antihypertensive pharmaceutical residues in the aquatic environment - A review. Chemosphere 2015, 138, 281-291. [CrossRef]

10. Cheng, D.; Ngo, H.H.; Guo, W.; Chang, S.W.; Nguyen, D.D.; Liu, Y.; Wei, Q.; Wei, D. A critical review on antibiotics and hormones in swine wastewater: Water pollution problems and control approaches. J. Hazard. Mater. 2020, 387, 121682. [CrossRef]

11. Sim, W.-J.; Lee, J.-W.; Lee, E.-S.; Shin, S.-K.; Hwang, S.-R.; Oh, J.-E. Occurrence and distribution of pharmaceuticals in wastewater from households, livestock farms, hospitals and pharmaceutical manufactures. Chemosphere 2011, 82, 179-186. [CrossRef]

12. Santos, L.H.; Gros, M.; Rodriguez-Mozaz, S.; Delerue-Matos, C.; Pena, A.; Barceló, D.; Montenegro, M.C.B.S.M. Contribution of hospital effluents to the load of pharmaceuticals in urban wastewaters: Identification of ecologically relevant pharmaceuticals. Sci. Total Environ. 2013, 461-462, 302-316. [CrossRef] [PubMed] 
13. Papageorgiou, M.; Zioris, I.; Danis, T.; Bikiaris, D.; Lambropoulou, D. Comprehensive investigation of a wide range of pharmaceuticals and personal care products in urban and hospital wastewaters in Greece. Sci. Total Environ. 2019, 694, 133565. [CrossRef] [PubMed]

14. Behera, S.K.; Kim, H.W.; Oh, J.-E.; Park, H.-S. Occurrence and removal of antibiotics, hormones and several other pharmaceuticals in wastewater treatment plants of the largest industrial city of Korea. Sci. Total Environ. 2011, 409, 4351-4360. [CrossRef] [PubMed]

15. World Health Organization. Pharmaceuticals in Drinking-Water; World Health Organization: Geneva, Switzerland, 2012.

16. IQVIA Institute for Human Data Sciences. The Global Use of Medicine in 2019 and Outlook to 2023-Forecasts and Areas to Watch; IQVIA: Durham, NC, USA, 2019.

17. Méndez-Arriaga, F.; Torres-Palma, R.A.; Pétrier, C.; Esplugas, S.; Gimenez, J.; Pulgarin, C. Ultrasonic treatment of water contaminated with ibuprofen. Water Res. 2008, 42, 4243-4248. [CrossRef]

18. Park, H.; Park, Y.; Kim, W.; Choi, W. Surface modification of $\mathrm{TiO}_{2}$ photocatalyst for environmental applications. J. Photochem. Photobiol. C Photochem. Rev. 2013, 15, 1-20. [CrossRef]

19. Choina, J.; Kosslick, H.; Fischer, C.; Flechsig, G.-U.; Frunza, L.; Schulz, A. Photocatalytic decomposition of pharmaceutical ibuprofen pollutions in water over titania catalyst. Appl. Catal. B Environ. 2013, 129, 589-598. [CrossRef]

20. Lin, L.; Jiang, W.; Bechelany, M.; Nasr, M.; Jarvis, J.; Schaub, T.; Sapkota, R.R.; Miele, P.; Wang, H.; Xu, P. Adsorption and photocatalytic oxidation of ibuprofen using nanocomposites of $\mathrm{TiO} 2$ nanofibers combined with BN nanosheets: Degradation products and mechanisms. Chemosphere 2019, 220, 921-929. [CrossRef]

21. Jallouli, N.; Pastrana-Martínez, L.M.; Ribeiro, A.R.; Moreira, N.F.F.; Faria, J.L.; Hentati, O.; Silva, A.M.T.; Ksibi, M. Heterogeneous photocatalytic degradation of ibuprofen in ultrapure water, municipal and pharmaceutical industry wastewaters using a TiO2/UV-LED system. Chem. Eng. J. 2018, 334, 976-984. [CrossRef]

22. Moro, P.; Donzello, M.P.; Ercolani, C.; Monacelli, F.; Moretti, G. Tetrakis-2,3-[5,6-di-(2-pyridyl)-pyrazino] porphyrazine and its $\mathrm{Cu}(\mathrm{II})$ complex as sensitizers in the TiO2-based photo-degradation of 4-nitrophenol. J. Photochem. Photobiol. Chem. 2011, 220,77-83. [CrossRef]

23. Simmler, W. Air, 6. Photochemical Degradation. In Ullmann's Encyclopedia of Industrial Chemistry; Wiley-VCH Verlag GmbH \& Co. KGaA: Weinheim, Germany, 2011; Volume 50, pp. 464-488. ISBN 0007-4977.

24. Byrne, C.; Subramanian, G.; Pillai, S.C. Recent advances in photocatalysis for environmental applications. J. Environ. Chem. Eng. 2018, 6, 3531-3555. [CrossRef]

25. Kanakaraju, D.; Glass, B.D.; Oelgemöller, M. Advanced oxidation process-mediated removal of pharmaceuticals from water: A review. J. Environ. Manag. 2018, 219, 189-207. [CrossRef] [PubMed]

26. Mozia, S.; Morawski, A.W. The performance of a hybrid photocatalysis-MD system for the treatment of tap water contaminated with ibuprofen. Catal. Today 2012, 193, 213-220. [CrossRef]

27. Hiroto, S.; Miyake, Y.; Shinokubo, H. Synthesis and Functionalization of Porphyrins through Organometallic Methodologies. Chem. Rev. 2017, 117, 2910-3043. [CrossRef] [PubMed]

28. Ziental, D.; Czarczynska-Goslinska, B.; Mlynarczyk, D.T.; Glowacka-Sobotta, A.; Stanisz, B.; Goslinski, T.; Sobotta, L. Titanium Dioxide Nanoparticles: Prospects and Applications in Medicine. Nanomaterials 2020, 10, 387. [CrossRef] [PubMed]

29. Zhang, H.; Banfield, J.F. Thermodynamic analysis of phase stability of nanocrystalline titania. J. Mater. Chem. 1998, 8, 2073-2076. [CrossRef]

30. Luttrell, T.; Halpegamage, S.; Tao, J.; Kramer, A.; Sutter, E.; Batzill, M. Why is anatase a better photocatalyst than rutile?-Model studies on epitaxial $\mathrm{TiO}_{2}$ films. Sci. Rep. 2014, 4, 1-8. [CrossRef] [PubMed]

31. Mele, G.; del Sole, R.; Vasapollo, G.; García-López, E.; Palmisano, L.; Jun, L.; Słota, R.; Dyrda, G. TiO 2 -based photocatalysts impregnated with metallo-porphyrins employed for degradation of 4-nitrophenol in aqueous solutions: Role of metal and macrocycle. Res. Chem. Intermed. 2007, 33, 433-448. [CrossRef]

32. Vignesh, K.; Rajarajan, M.; Suganthi, A. Photocatalytic degradation of erythromycin under visible light by zinc phthalocyanine-modified titania nanoparticles. Mater. Sci. Semicond. Process. 2014, 23, 98-103. [CrossRef]

33. Fadel, M.; Kassab, K.; Abdel Fadeel, D. Zinc phthalocyanine-loaded PLGA biodegradable nanoparticles for photodynamic therapy in tumor-bearing mice. Lasers Med. Sci. 2010, 25, 283-292. [CrossRef] 
34. Cabir, B.; Yurderi, M.; Caner, N.; Agirtas, M.S.; Zahmakiran, M.; Kaya, M. Methylene blue photocatalytic degradation under visible light irradiation on copper phthalocyanine-sensitized $\mathrm{TiO}_{2}$ nanopowders. Mater. Sci. Eng. B 2017, 224, 9-17. [CrossRef]

35. Altın, İ.; Sökmen, M.; Bıyıklığlu, Z. Quaternized zinc(II) phthalocyanine-sensitized TiO ${ }_{2}$ : Surfactant-modified sol-gel synthesis, characterization and photocatalytic applications. Desalin. Water Treat. 2016, 57, 16196-16207. [CrossRef]

36. Flak, D.; Yate, L.; Nowaczyk, G.; Jurga, S. Hybrid ZnPc@ $\mathrm{TiO}_{2}$ nanostructures for targeted photodynamic therapy, bioimaging and doxorubicin delivery. Mater. Sci. Eng. C 2017, 78, 1072-1085. [CrossRef] [PubMed]

37. Theivasanthi, T.; Alagar, M. Titanium dioxide $\left(\mathrm{TiO}_{2}\right)$ Nanoparticles XRD Analyses: An Insight. arXiv 2013, arXiv:13071091.

38. Duan, M.; Li, J.; Li, M.; Zhang, Z.; Wang, C. Pt(II) porphyrin modified $\mathrm{TiO}_{2}$ composites as photocatalysts for efficient 4-NP degradation. Appl. Surf. Sci. 2012, 258, 5499-5504. [CrossRef]

39. Huang, Z.; Zheng, B.; Zhu, S.; Yao, Y.; Ye, Y.; Lu, W.; Chen, W. Photocatalytic activity of phthalocyanine-sensitized TiO2-SiO2 microparticles irradiated by visible light. Mater. Sci. Semicond. Process. 2014, 25, 148-152. [CrossRef]

40. Mali, S.S.; Kim, H.; Kim, J.H.; Patil, P.S.; Kook Hong, C. Synthesis and characterization of planar heterojunction hybrid polymer solar cells based on copper pthalocyanine $(\mathrm{CuPc})$ and titanium dioxide. Ceram. Int. 2014, 40, 643-649. [CrossRef]

41. Soema, P.C.; Willems, G.-J.; Jiskoot, W.; Amorij, J.-P.; Kersten, G.F. Predicting the influence of liposomal lipid composition on liposome size, zeta potential and liposome-induced dendritic cell maturation using a design of experiments approach. Eur. J. Pharm. Biopharm. 2015, 94, 427-435. [CrossRef]

42. Kozlov, N.K.; Natashina, U.A.; Tamarov, K.P.; Gongalsky, M.B.; Solovyev, V.V.; Kudryavtsev, A.A.; Sivakov, V.; Osminkina, L.A. Recycling of silicon: From industrial waste to biocompatible nanoparticles for nanomedicine. Mater. Res. Express 2017, 4, 95026. [CrossRef]

43. World Health Organization. WHO Model List of Essential Medicines, 21st ed.; World Health Organization: Geneva, Switzerland, 2019.

44. Kanabar, D.J. A clinical and safety review of paracetamol and ibuprofen in children. Inflammopharmacology 2017, 25, 1-9. [CrossRef]

45. Kaufman, D.W.; Kelly, J.P.; Battista, D.R.; Malone, M.K.; Weinstein, R.B.; Shiffman, S. Exceeding the daily dosing limit of nonsteroidal anti-inflammatory drugs among ibuprofen users. Pharmacoepidemiol. Drug Saf. 2018, 27, 322-331. [CrossRef]

46. Tixier, C.; Singer, H.P.; Oellers, S.; Müller, S.R. Occurrence and Fate of Carbamazepine, Clofibric Acid, Diclofenac, Ibuprofen, Ketoprofen and Naproxen in Surface Waters. Environ. Sci. Technol. 2003, 37, 1061-1068. [CrossRef] [PubMed]

47. Miège, C.; Choubert, J.M.; Ribeiro, L.; Eusèbe, M.; Coquery, M. Fate of pharmaceuticals and personal care products in wastewater treatment plants-Conception of a database and first results. Environ. Pollut. 2009, 157, 1721-1726. [CrossRef] [PubMed]

48. Pereira, A.; Silva, L.; Laranjeiro, C.; Lino, C.; Pena, A. Selected Pharmaceuticals in Different Aquatic Compartments: Part I-Source, Fate and Occurrence. Molecules 2020, 25, 1026. [CrossRef] [PubMed]

49. Simazaki, D.; Kubota, R.; Suzuki, T.; Akiba, M.; Nishimura, T.; Kunikane, S. Occurrence of selected pharmaceuticals at drinking water purification plants in Japan and implications for human health. Water Res. 2015, 76, 187-200. [CrossRef] [PubMed]

50. Peñas-Garzón, M.; Gómez-Avilés, A.; Belver, C.; Rodriguez, J.J.; Bedia, J. Degradation pathways of emerging contaminants using TiO2-activated carbon heterostructures in aqueous solution under simulated solar light. Chem. Eng. J. 2020, 392, 124867. [CrossRef]

51. Achilleos, A.; Hapeshi, E.; Xekoukoulotakis, N.P.; Mantzavinos, D.; Fatta-Kassinos, D. UV-A and Solar Photodegradation of Ibuprofen and Carbamazepine Catalyzed by $\mathrm{TiO}_{2}$. Sep. Sci. Technol. 2010, 45, 1564-1570. [CrossRef]

52. Da Silva, J.C.C.; Teodoro, J.A.R.; de Cássia Franco Afonso, R.J.; Aquino, S.F.; Augusti, R. Photolysis and photocatalysis of ibuprofen in aqueous medium: Characterization of by-products via liquid chromatography coupled to high-resolution mass spectrometry and assessment of their toxicities against Artemia Salina. J. Mass Spectrom. 2014, 49, 145-153. [CrossRef] 
53. Romeiro, A.; Azenha, M.E.; Canle, M.; Rodrigues, V.H.N.; Da Silva, J.P.; Burrows, H.D. Titanium Dioxide Nanoparticle Photocatalysed Degradation of Ibuprofen and Naproxen in Water: Competing Hydroxyl Radical Attack and Oxidative Decarboxylation by Semiconductor Holes. ChemistrySelect 2018, 3, 10915-10924. [CrossRef]

54. Jiménez-Salcedo, M.; Monge, M.; Tena, M.T. Photocatalytic degradation of ibuprofen in water using TiO2/UV and g-C3N4/visible light: Study of intermediate degradation products by liquid chromatography coupled to high-resolution mass spectrometry. Chemosphere 2019, 215, 605-618. [CrossRef]

55. Patterson, K.; Howlett, K.; Patterson, K.; Wang, B.; Jiang, L. Photodegradation of ibuprofen and four other pharmaceutical pollutants on natural pigments sensitized $\mathrm{TiO}_{2}$ nanoparticles. Water Environ. Res. 2020. [CrossRef]

56. Méndez-Arriaga, F.; Esplugas, S.; Giménez, J. Photocatalytic degradation of non-steroidal anti-inflammatory drugs with TiO2 and simulated solar irradiation. Water Res. 2008, 42, 585-594. [CrossRef] [PubMed]

57. Bhatia, $\mathrm{V}$; Dhir, A. Transition metal doped $\mathrm{TiO}_{2}$ mediated photocatalytic degradation of anti-inflammatory drug under solar irradiations. J. Environ. Chem. Eng. 2016, 4, 1267-1273. [CrossRef]

58. Agustina, T.E.; Ang, H.M.; Vareek, V.K. A review of synergistic effect of photocatalysis and ozonation on wastewater treatment. J. Photochem. Photobiol. C Photochem. Rev. 2005, 6, 264-273. [CrossRef]

59. Ogunsipe, A.; Chen, J.-Y.; Nyokong, T. Photophysical and photochemical studies of zinc(II) phthalocyanine derivatives-Effects of substituents and solvents. New J. Chem. 2004, 28, 822-827. [CrossRef]

60. Li, G.; Lv, L.; Fan, H.; Ma, J.; Li, Y.; Wan, Y.; Zhao, X.S. Effect of the agglomeration of $\mathrm{TiO}_{2}$ nanoparticles on their photocatalytic performance in the aqueous phase. J. Colloid Interface Sci. 2010, 348, 342-347. [CrossRef]

61. Johnson, B.T. Microtox@Acute Toxicity Test. In Small-scale Freshwater Toxicity Investigations; Blaise, C., Férard, J.-F., Eds.; Springer: Berlin/Heidelberg, Germany, 2005; pp. 69-105. ISBN 978-1-4020-3119-9.

62. Czech, B.; Jośko, I.; Oleszczuk, P. Ecotoxicological evaluation of selected pharmaceuticals to Vibrio fischeri and Daphnia magna before and after photooxidation process. Ecotoxicol. Environ. Saf. 2014, 104, 247-253. [CrossRef]

63. Shemer, H.; Linden, K.G. Photolysis, oxidation and subsequent toxicity of a mixture of polycyclic aromatic hydrocarbons in natural waters. J. Photochem. Photobiol. Chem. 2007, 187, 186-195. [CrossRef]

64. Lü, X.; Li, J.; Wang, C.; Duan, M.; Luo, Y.; Yao, G.; Wang, J.-L. Enhanced photoactivity of CuPp-TiO 2 photocatalysts under visible light irradiation. Appl. Surf. Sci. 2010, 257, 795-801. [CrossRef]

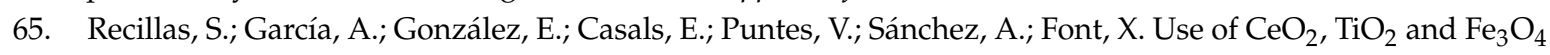
nanoparticles for the removal of lead from water. Desalination 2011, 277, 213-220. [CrossRef]

Publisher's Note: MDPI stays neutral with regard to jurisdictional claims in published maps and institutional affiliations.

(C) 2020 by the authors. Licensee MDPI, Basel, Switzerland. This article is an open access article distributed under the terms and conditions of the Creative Commons Attribution (CC BY) license (http://creativecommons.org/licenses/by/4.0/). 